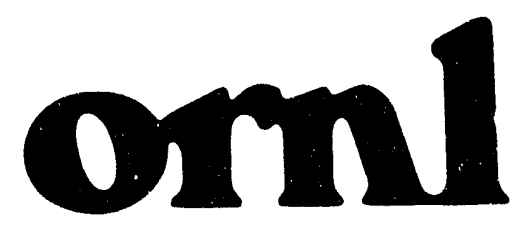

OAK RIDGE NATIONAL LABORATORY
ORNL/ENG/TM-40

\title{
DYNAMIC IMPACT ANALYSIS OF THE M1 105MM PROJECTILE
}

MARTIN MARIETTA

J. C. Walls

D. S. Webb

\section{' MANAGED BY}

MARTIN MARIETTA ENERGY SYSTEMS, INC.

FOR THE UNITEO STATES

DEPARTMENT OF ENERGY 
This report has been reproduced directly from the best available copy.

Available to DOE and DOE contractors from the Office of Scientific and Technical Information, P.O. Box 62, Oak Ridge, TN 37831; prices available from (615) 576-8401, FTS 626-8401.

Available to the public from the National Technical Information Service, U.S. Department of Commerce, 5285 Port Royal Rd., Springfield, VA 22161.

This report was prepared as an account of work sponsored by an agency of the United States Government. Neither the United States Government nor any agency thereof, nor any of their employees, makes any warranty, express or implied, or assumes any legal liability or responsibility for the accuracy, completeness, or usefulness of any information, apparatus, product, or process disclosed, or represents that its use would not infringe privately owned rights. Reference herein to any specific commercial product, process, or service by trade name, trademark, manufacturer, or otherwise, does not necessarily constitute or imply its endorsement, recommendation, or favoring by the United States Government or any agency thereof. The views and opinions of authors expressed herein do not necessarily state or reflect those of the United States Government or any agency thereor. 
Central Engineering Services

\title{
DYNAMIC IMPACT ANALYSIS OF THE M1 105MM PROJECTILE
}

\author{
J. C. Walls
}

D. S. Webb

June 1993

Research sponsored by the Packaging Division, Armament

Research, Development and Engineering Center (ARDEC),

Picatinny Arsenal under Interagency Agreement 1892-A078-A1

between the U.S. Department of Energy and ARDEC.

Prepared by the

OAK RIDGE NATIONAL LABORATORY

Oak Ridge, Tennessee 37831-6285

managed by

MARTIN MARIETTA ENERGY SYSTEMS, INC.

for the

U.S. DEPARTMENT OF ENERGY

under contract DE-AC05-84OR21400 
CONTENTS

$\underline{\text { Page }}$

LIST OF FIGURES $\ldots \ldots \ldots \ldots \ldots \ldots \ldots \ldots \ldots \ldots \ldots \ldots$

ABSTRACT $\ldots \ldots \ldots \ldots \ldots \ldots \ldots \ldots \ldots \ldots \ldots \ldots \ldots \ldots \ldots \ldots \ldots \ldots$

INTRODUCTION AND BACKGROUND $\ldots \ldots \ldots \ldots \ldots \ldots \ldots \ldots$

DESCRIPTION OF THE PACKAGE CONFIGURATIONS ANALYZED $\ldots \ldots \ldots \ldots$

FINITE ELEMENT MODELS $\ldots \ldots \ldots \ldots \ldots \ldots \ldots \ldots \ldots$

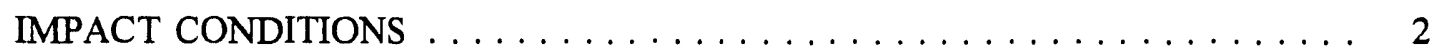

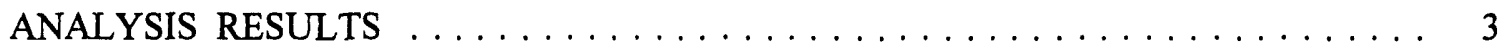

BARE PROJECTILE $\ldots \ldots \ldots \ldots \ldots \ldots \ldots \ldots \ldots \ldots \ldots \ldots \ldots$

Bare Projectile Impacting Flat onto Its Nose $\ldots \ldots \ldots \ldots \ldots \ldots$

Bare Projectile Impacting Flat onto Its Base $\ldots \ldots \ldots \ldots \ldots \ldots \ldots$

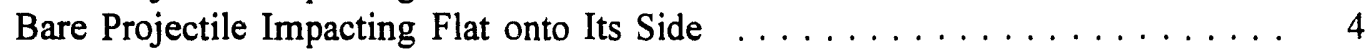

Bare Projectile Impacting at $45^{\circ}$ Angle on Its Nose $\ldots \ldots \ldots \ldots$

PROJECTILE IN A FIBER TUBE $\ldots \ldots \ldots \ldots \ldots \ldots \ldots \ldots \ldots \ldots$

PROJECTILES INSIDE A WOODEN SHIPPING CRATE $\ldots \ldots \ldots \ldots \ldots$

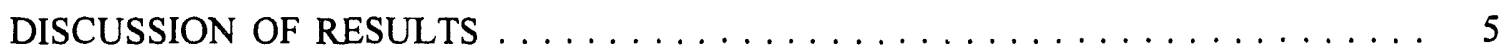

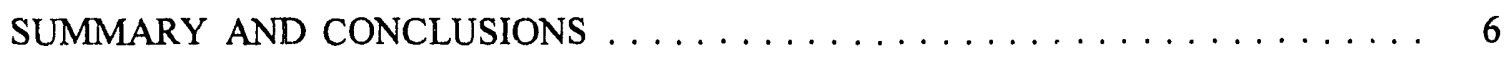

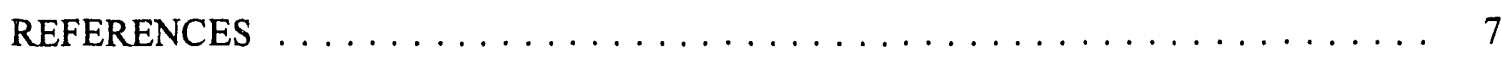




\section{LIST OF FIGURES}

No.

Title

$\underline{\text { Page }}$

1 Typical M1 105MM Howitzer artillery shell $\ldots \ldots \ldots \ldots \ldots \ldots \ldots \ldots$

2 Projectile section and finite element model showing general location

of high residual tensile stresses $\ldots \ldots \ldots \ldots \ldots \ldots \ldots \ldots \ldots \ldots$

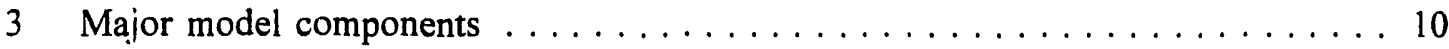

4 Model components for the fiber ammunition tube drop cases $\ldots \ldots \ldots \ldots \ldots 11$

5 Model components for the fiber ammunition tube drop cases . . . . . . . . . 12

6 Cutaway view of the wooden shipping crate model $\ldots \ldots \ldots \ldots \ldots \ldots \ldots$

7 Rigid body acceleration for bare projectile dropped flat on nose $\ldots \ldots \ldots \ldots$.

8 Projectile velocity, bare projectile dropped flat on nose $\ldots \ldots \ldots \ldots \ldots$

9 Kinetic energy, bare projectile dropped flat on nose $\ldots \ldots \ldots \ldots$

10 Elements in nose region of bare projectile model $\ldots \ldots \ldots \ldots \ldots \ldots$

11 Time history of maximum principal stress in elements 537 and $538 \ldots \ldots 18$

12 Time history of maximum principal stress in elements 505 and $506 \ldots \ldots 19$

13 Time history of maximum principal stress in elements 473 and $474 \ldots \ldots \ldots 20$

14 Projectile acceleration, bare projectile dropped flat on base $\ldots \ldots \ldots \ldots$

15 Element numbers in nose region of model $\ldots \ldots \ldots \ldots \ldots \ldots \ldots \ldots \ldots$

16 Time history of maximum principal stress in elements 521 and $522 \ldots \ldots \ldots$

17 Time history of maximum principal stress in elements 489 and $490 \ldots \ldots \ldots 24$

18 Time history of maximum principal stress in elements 457 and $458 \ldots \ldots \ldots 25$

19 Projectile acceleration, bare projectile dropped flat on side $\ldots \ldots \ldots \ldots \ldots$

20 Kinetic energy vs time for bare projectile impacting at $45^{\circ} \ldots \ldots \ldots \ldots \ldots$

21 Element numbers in nose region of projectile for $45^{\circ}$ impact case $\ldots \ldots \ldots 28$ 
22 Time history of maximum principal stress for elements $670-672 \ldots \ldots \ldots$

23 Time history of maximum principal stress for elements $718-720 \ldots \ldots \ldots$

24 Time history of maximum principal stress for elements $667-669 \ldots \ldots \ldots \ldots$

25 Projectile acceleration, projectile in fiber tube dropped flat

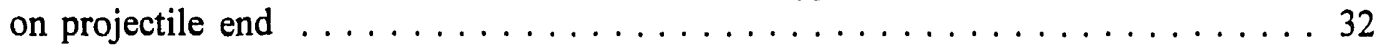

26 Peak axial stress, projectile in fiber tube dropped flat on projectile end $\ldots \ldots \ldots \ldots \ldots \ldots \ldots \ldots \ldots \ldots \ldots \ldots \ldots \ldots \ldots$

27 Projectile acceleration, projectile in fiber tube dropped flat

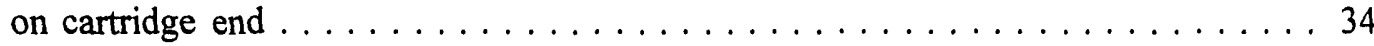

28 Peak von Mises stress, projectile in fiber tube dropped flat

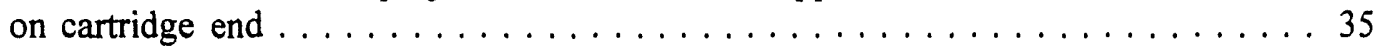

29 Projectile acceleration, projectile in fiber tube dropped flat on side $\ldots \ldots \ldots . \ldots 36$

30 Peak von Mises stress, projectile in fiber tube dropped flat on side $\ldots \ldots \ldots 37$

31 Projectile acceleration, projectile in wooden shipping crate dropped

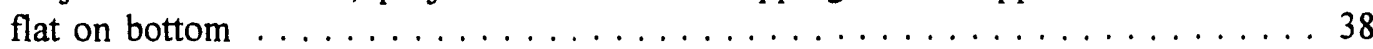

32 Peak von Mises stress, projectile in wooden shipping crate dropped flat on bottom ............................. 39

33 Projectile acceleration, projectile in wooden shipping crate dropped flat on projectile end

34 Peak von Mises stress, projectile in wooden shipping crate dropped flat on projectile end 


\begin{abstract}
Evaluation of the effects of "rough-handling"-induced stresses in the nose region of a $105 \mathrm{~mm}$ artillery projectile was performed to determine if these stresses could have contributed to the premature explosion of a projectile during a Desert Shield training mission of the 101st Army Airborne in Saudi Arabia. The rough-handling evaluations were simulated by dynamic impact analysis. It was concluded that the combined residual stress and dynamic impact-induced stress would not be of sufficient magnitude to cause cracking of the projectile in the nose region.
\end{abstract}




\section{INTRODUCTION AND BACKGROUND}

An in-bore premature explosion of an M1 $105 \mathrm{~mm}$ Howitzer artillery projectile (Fig. 1) was reported to have occurred during a Desert Shield training mission of the 101st Army Airborne in Saudi Arabia. One possible reason for this failure was thought to be nose cracks in the projectile resulting from either rough handling, high residual stresses, and/or manufacturing defects. ${ }^{1}$ Figure 2 shows a typical $105 \mathrm{~mm}$ projectile as well as the location of potential nose cracks.

Results of tensile tests performed on material from the nose area of two projectile bodies from the malfunctioned round $\operatorname{lot}^{1}$ show that the material strength averaged about $103 \mathrm{ksi}$, which is well above the required $65-\mathrm{ksi}$ value. This high strength may be an indication that a significant stress relief was not performed. ' Also, high tensile residual stresses were detected in the nose area of M1 projectiles from the malfunctioned round lot. The maximum tensile residual stresses are located on the inside wall surface (see Fig. 2), are oriented in the hoop direction, and are on the order of one-third the yield stress. ${ }^{1}$ The magnitude of these residual stresses would also indicate that the shells were not properly stress relieved and would be readily susceptible to the generation of longitudinal cracks when subjected to rough handling or excessive acceleration loads. If these conditions occur at extremely low temperatures, brittle fracture may become a consideration.

Considering the results of the residual stress and material tensile sirength determinations, the objective of this report is to evaluate the effects of "rough-handling"-induced stresses and determine if these stresses could have contributed to the projectile failure.

The rough-handling evaluations were simulated by dynamic impact analysis. Finite element models were formulated for the projectile, cartridge case, fiber tube assembly, and the wooden shipping crate in which the projectiles are shipped. These models were then used to simulate drops from a 7-ft height onto an unyielding surface for various orientations and package configurations. The resulting accelerations and stresses were then analyzed to determine if the drop scenarios could have induced cracks and influenced premature failure of the projectile.

Actual drop testing of some of the projectile configurations were conducted at Picatinny Arsenal. However, limited accelerometer data were available for comparison with the dynamic analysis results reported herein. In this regard, a secondary objective of this report was to verify that computer code predictive methodologies could be a cost-effective alternative to physical testing of armament packaging.

\section{DESCRIPTION OF THE PACKAGE CONFIGURATIONS ANALYZED}

The M1 105mm projectile, along with other components that comprise the artillery shell, is shipped inside a wooden shipping crate. The shipping crate contains components for two complete artillery rounds. Each individual projectile and cartridge case within the wooden crate is enclosed inside a fiber tube along with protector cones, washers, and end caps. The details of the components of the M1 $105 \mathrm{~mm}$ artillery round, the wooden box, and all the other items contained in the box for shipping are defined by the drawings and 
specifications obtained from Packaging Division, Armament Research, Development and Engineering Center (ARDEC), Picatinny Arsenal, and are shown in Table 1.

Table 1. Drawings and specifications used to define package configurations

\begin{tabular}{ll}
\hline \multicolumn{1}{c}{ Drawing/specification } & \multicolumn{1}{c}{ Description } \\
\hline 10535878 & Projectile body \\
8595386 & Cartridge case \\
9258026 & Fiber ammunition container \\
9258027 & Fiber ammunition container \\
9271050 & Fiber ammunition container \\
Specification MIL-C-2439E & Fiber ammunition container \\
Specification MIL-B-2427G & Wooden shipping crate \\
\hline
\end{tabular}

\section{FINITE ELEMENT MODELS}

Finite element models were generated to simulate the various components of the M1 $105 \mathrm{~mm}$ shell and its packaged configuration for the dynamic impact analyses. All models were formulated and analyzed with the VEC/DYNA3D, ${ }^{2}$ INGRID, ${ }^{3}$ and TAURUS ${ }^{4}$ finite element computer codes. The codes reside on a Silicon Graphics 4D/35 engineering workstation computer. INGRID is a preprocessor code that was used to formulate the various models and components. Figures 3 through 6 show the various components and how they were assembled for the dynamic analyses.

Three different projectile/package models were analyzed. The first configuration analyzed was the bare projectile without the fuse or fuse plug. The second configuration consisted of a projectile contained within the fiber ammunition tube. An exploded view of the model components can be seen in Fig. 4. The third package configuration model consisted of the complete wooden shipping crate with two projectiles and all the packaged components. An exploded view of this model is shown in Fig. 5. A cutaway view of the complete wooden shipping crate model is shown in Fig. 6.

Material properties used for the projectile were a modulus of elasticity of $29 \times 10^{6} \mathrm{psi}$ and a yield strength of $110,000 \mathrm{psi}^{5}$ Material properties for some of the components in the wooden shipping crate were estimated. The properties of the wooden box were assumed to be generic plywood. Similarly, the properties of the fiber ammunition tube material were assumed.

\section{IMPACT CONDITIONS}

The drop height used for all analyses was taken as $7 \mathrm{ft}$. Also, all impacts were assumed to be onto a flat, unyielding surface. The assumption of an unyielding surface will most 
likely cause accelerations and stress magnitudes in the projectile to be conservatively predicted because actual surfaces are more flexible, which tends to lower stresses in the projectile.

The bare projectile model impact response was examined for four different orientations of the projectile at impact. These were (1) projectile impacting flat onto its nose,

(2) projectile impacting flat onto its base, (3) projectile impacting flat onto its side, and

(4) projectile impacting at an angle of $45^{\circ}$ to the surface onto its nose.

The projectile in its fiber shipping tube model was analyzed for three different impact orientations. These were (1) tube impacting flat onto the projectile end of the model, (2) tube impacting flat onto the cartridge end of the model, and (3) tube impacting flat onto its side.

The complete wooden shipping crate model was analyzed for two different impact orientations: flat onto the crate bottom and flat onto the projectile end of the crate.

\section{ANALYSIS RESULTS}

As previously mentioned, three different projectile/package models were analyzed: (1) a bare projectile, (2) a projectile in a fiber tube, and (3) a complete wooden shipping crate with two projectiles. Results of the analyses are given in the following paragraphs.

\section{BARE PROJECTLE}

The bare projectile model was analyzed for four different orientations of the projectile at impact. There were (1) projectile impacting flat onto its nose, (2) projectile im:pacting flat onto its base, (3) projectile impacting flat onto its side, and (4) projectile impacting at an angle of $45^{\circ}$ to the surface onto its nose. Results of the analyses are given below.

\section{Bare Projectile Impacting Flat onto Its Nose}

The dynamic impact of the bare projectile model impacting the rigid, unyielding surface flat onto its nose was analyzed with the VEC/DYNA3D computer code. Accelerations, velocities, kinetic energy, stresses, strains, and deformations can be obtained for the model at any time in the impact event and examined with the postprocessor, TAURUS. For this impact simulation, for example, Figs. 7 to 9 show the acceleration, velocity, and kinetic energy vs time. The plot of kinetic energy is often used to verify that the impact event is being simulated correctly. A smooth kinetic energy curve usually indicates that energy is being expended without computational difficulties in the finite element model.

The large values of acceleration indicated by Fig. 7 occur at times early in the impact event and are indicative of the relatively rigid projectile impacting the rigid, unyielding surface. It should be noted that the assumption of the rigid, unyielding impact surface is quite conservative; and it is therefore likely that accelerations, stresses, etc., will be overestimated for this analysis.

Since tensile stresses in the nose region of the projectile are of interest, a time history of maximum principal stresses was recorded for elements in this region. Figure 10 indicates the location of elements in the nose region of the bare projectile. Figures 11 to 13 show time 
histories of the maximum principal stress in selected elements in the nose region of the projectile. From these plots it is seen that peak stresses of $\sim 20,000$ psi are indicated.

\section{Bare Projectile Impacting Flat onto Its Base}

The projectile acceleration vs time for the base impact scenario is shown in Fig. 14. As mentioned previously, the combination of a relatively rigid projectile model impacting an unyielding surface creates a sharply defined maximum acceleration at impact.

As before, tensile stresses in the nose region of the projectile are of concern. Figure 15 shows the element numbering scheme for this impact model. Maximum principal stresses vs time are plotted in Figs. 16 to 18 for typical elements in the nose region of the projectile. For this impact scenario, the maximum values of stress are of the order of $31,000 \mathrm{psi}$.

\section{Bare Projectile Impacting Flat onto Its Side}

The projectile acceleration vs time for the side impact event is recorded in Fig. 19. It is seen that the acceleration levels are much less than those obtained from the nose and base impact events. The lower level of acceleration is probably a result of greater flexibility of the projectile model for loads acting on the sides of the projectile. Also, for this case, stress levels in the nose area of the projectile were examined and found to be of the order of 10,000 psi or less.

\section{Bare Projectile Impacting at $45^{\circ}$ Angle on Its Nose}

The scenario of a base projer ile impacting the unyielding surface at an angle of $45^{\circ}$ on its nose was analyzed. This evert is much more complex than the other base projectile impact events and includes a simulation of initial impact and rotation of the projectile until secondary impact occurs. A plot of the kinetic energy dissipation is shown in Fig. 20.

Locations of elements in the nose region of the projectile are indicated in Fig. 21. It is noted that the point of impact occurs on the line of nodes between elements 531 and 576 . Maximum principal stresses were examined for several of the elements in the nose region for this impact event. From the stress results plotted in Figs. 22 to 24, it is seen that maximum values approach 50,000 psi.

\section{PROJECTILE IN A FIBER TUBE}

Impact simulations of the projectile and cartridge packaged in the fiber ammunition tube were analyzed for three different orientations at surface impact. The orientations were for flat-end impacts at both the projectile and cartridge ends of the tube and for flat impact onto the tube side. As would be expected, maximum accelerations and stresses experienced by the projectile are much less in the fiber tube when compared to results from the bare projectile impact simulations.

Results of the impact analyses are shown in Figs. 25 to 30 for the three different impact orientations. The results for the tube impacting the projectile end are shown in Figs. 25 and 26. Maximum acceleration is $2480 \mathrm{~g}$, and maximum stress in the projectile is $<20,000$ psi. For impact on the cartridge end, accelerations are quite low (Fig. 27) because of the cushioning effect of the protector cone inside the fiber tube. Also, for this case, stresses in 
the nose region of the projectile are generally less than 10,000 psi (Fig. 28). Results of the side impact indicate that maximum accelerations reach $1000 \mathrm{~g}$ (Fig. 29), but maximum stresses in the nose area of the projectile are less than 10,000 psi.

\section{PROJECTILES INSIDE A WOODEN SHIPPING CRATE}

Impact simulations of a wooden shipping crate containing two fiber ammunition tubes were completed for two different impact orientations: flat on the projectile end of the crate and flat onto the bottom of the crate.

The inclusion of the wooden box in the impact model results in smaller values of acceleration experienced by the projectiles as compared to previous configurations. For the case of a crate dropped flat on its bottom, Fig. 31 indicates that the maximum acceleration is $770 \mathrm{~g}$. Maximum stresses experienced by the projectile in the nose region are less than 10,000 psi, as shown by Fig. 32. Results of the case of crate dropped on its projectile end are shown in Figs. 33 and 34. Maximum accelerations are $355 \mathrm{~g}$, and stresses in the nose regions of the projectile are $<10,000$ psi.

\section{DISCUSSION OF RESULTS}

Dynamic impact simulations were performed on the M1 $105 \mathrm{~mm}$ projectile in a variety of packaged configurations and impact orientations. As might be expected, the maximum accelerations and maximum principal stress levels in the projectile are experienced for the bare projectile impact configuration. Review of results from the bare projectile impact simulations show that maximum principal stress levels in the nose region of the projectile occur for the $45^{\circ}$ angle impact orientation of the projectile. For this case, stress values approach 50,000 psi.

As was stated in the introduction, studies have shown that tensile residual stresses of 30,000 to 35,000 psi could exist in the nose region of the projectile. However, it is also indicated that these high residual stresses could exist only if proper stress relieving of the projectile were not performed. Also, when these high residual stresses are present, the material yield strength is 100,000 psi or greater. If the maximum principal stress obtained in the impact scenarios $(50,000 \mathrm{psi})$ is combined with a potential residual stress $(35,000 \mathrm{psi})$, the summation is still less than the material yield stress.

Drop testing of the M1 projectile has been performed. ${ }^{6}$ Results obtained from an accelerometer attached to the base of the M1 projectile were recorded for some impact orientations and packaged configurations. For a bare projectile dropped flat onto its side, a maximum acceleration of $2915 \mathrm{~g}$ was recorded from the test. For the bare projectile impact simulation reported herein, a value of $7165 \mathrm{~g}$ was indicated. This difference could be attributed to conservative assumptions in the model material data and also to the rigid, unyielding surface assumed for the analysis. Another consideration is the fact that the test accelerometer response time may underestimate sharp acceleration peaks that occur for the bare projectile impact. For the case of a projectile contained in a fiber tube, test accelerations for a flat side impact were measured to be $1744 \mathrm{~g}$, while the analysis indicated a value of $1000 \mathrm{~g}$. Finally, for the wooden shipping crate configuration, test accelerations were $719 \mathrm{~g}$, while analysis results were $770 \mathrm{~g}$. A much better correlation between test accelerations and analysis accelerations is obtained for the shipping crate configuration. This 
supports the idea that hardness of both the impacting item and the impacted surface irifluence accelerations obtained in the dynamic simulation analysis.

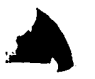

\section{SUMMARY AND CONCLUSIONS}

Results from the dynamic impact analysis indicate that maximum principal tensile stresses of $\sim 50,000$ psi occur in the nose of a bare projectile impacting an unyielding surface at a $45^{\circ}$ angle of incidence. If preexisting residual stresses were present, the impact-induced stress would combine to raise the stress levels to $\sim 85,000$ psi. Considering that yield strength for the projectile material is greater than $100,000 \mathrm{psi}$, it is believed that the combined residual stress and dynamic impact-induced stress would not be of sufficient magnitude to cause cracking of the projectile in the nose region.

It is felt that reasonably goc 1 comparisons were obtained between limited test data and the analysis, considering the assumptions made in the analysis. Therefore, it is concluded that dynamic impact analyses can be a valuable and cost-effective alternative to physical testing of ammunition and shipping packages. 


\section{REFERENCES}

1. K. F. Lukens, Malfunction Investigation of an In-Bore Explosion of an M1, 105MM Projectile - MIF A-2-91, Report No. MMB-02-92 (Draft), ARDEC, Picatinny Arsenal, N.J., Feb. 7, 1992.

2. John O. Hallquist and Douglas W. Stillman, VEC/DYNA3D User's Manual (Nonlinear Dynamic Analysis of Structures in Three Dimensions), LSTC Report 1018, June 1990.

3. John O. Hallquist and Douglas W. Stillman, INGRID: A Three-Dimensional Mesh Generator for Modeling Nonlinear Systems, UCID-10506, Lawrence Livermore Laboratory,.. July 1985.

4. John O. Hallquist and B. E. Brown, TAURUS: An Interactive Post-Process for the Analysis Codes NIKE3D, DYNA3D, TACO3D, and GEMINI, UCID-19392, Rev. 1, Lawrence Livermore Laboratory, May 1984.

5. Personai communication with J. C. Walls, Martin Marietta Energy Systems, Inc., and Tony D'Angelo, Picatinny Packaging Division.

6. Personal communication, J. C. Walls, Martin Marietta Energy Systems, Inc., and Gene Farrell, Picatinny Arsenal, Aug. 10, 1992. 


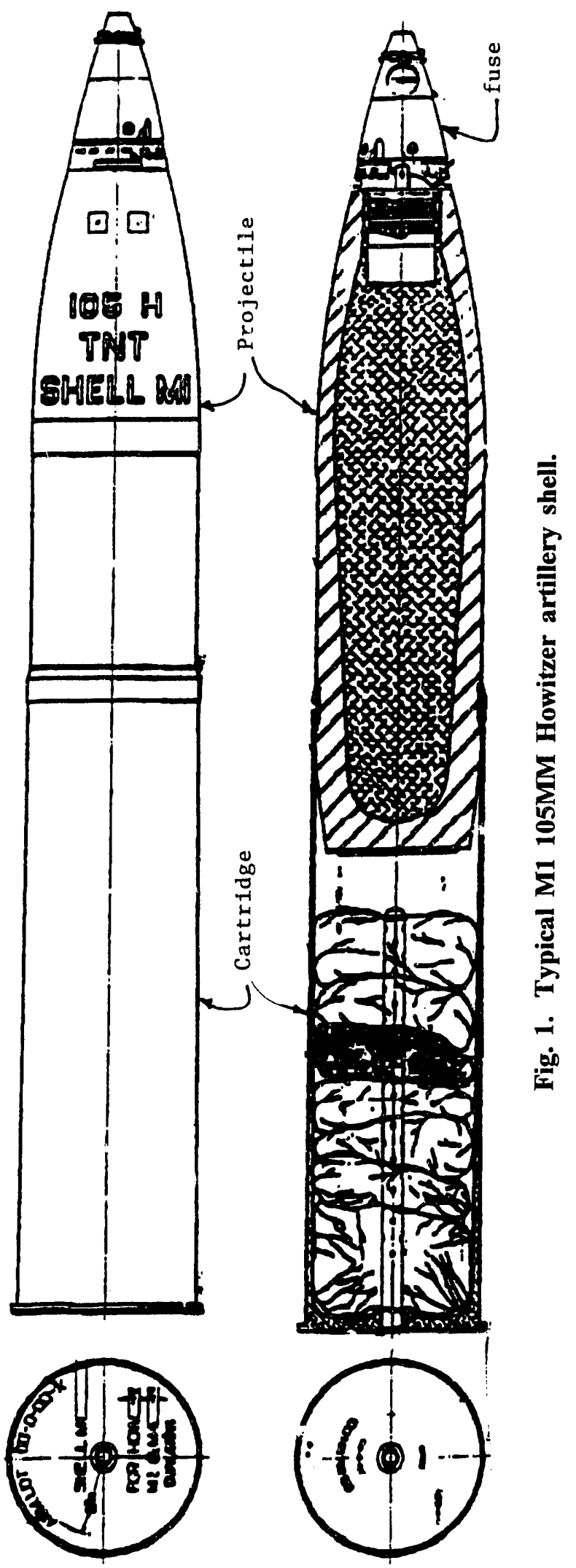



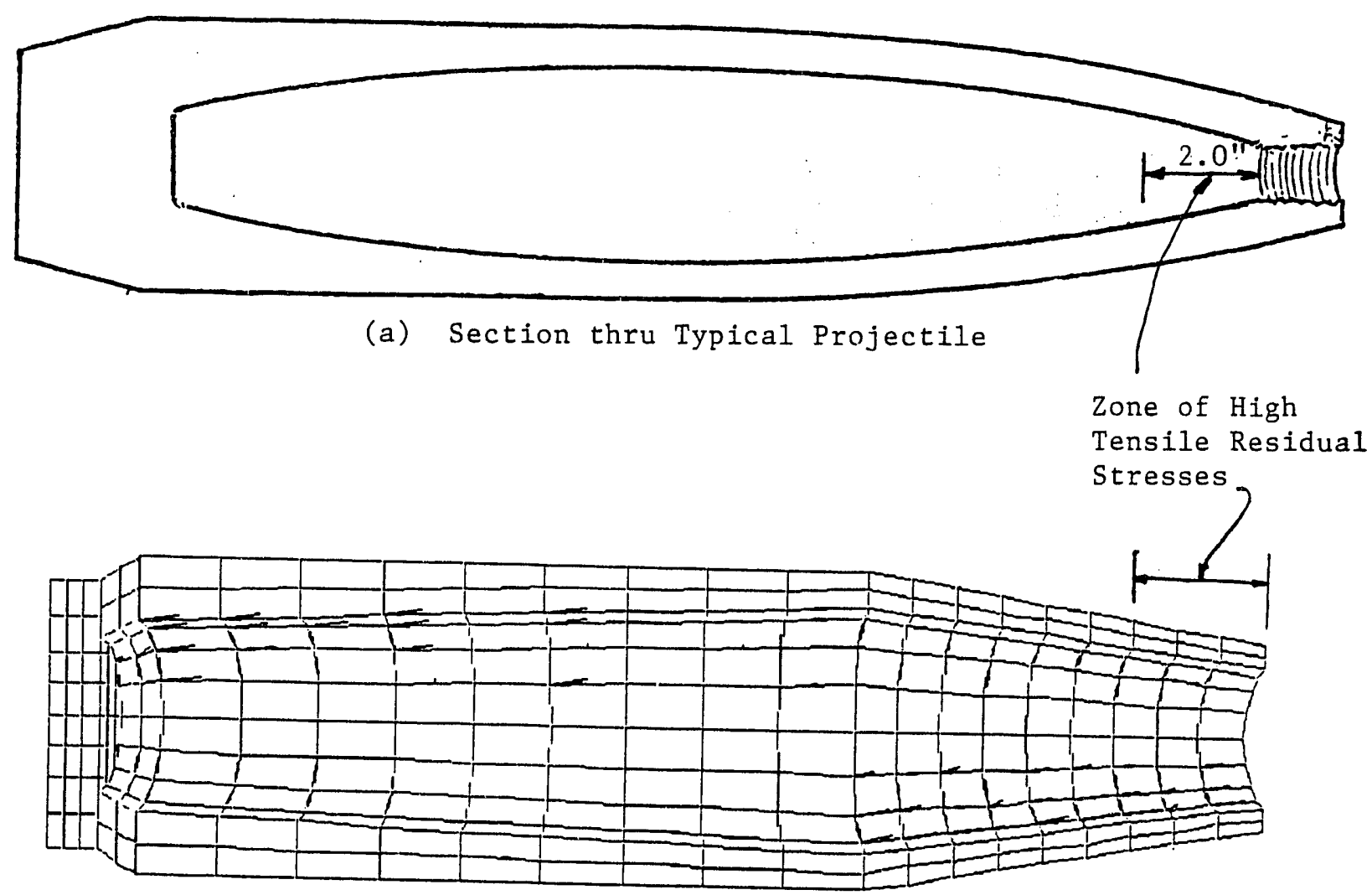

(b) Finite Element Model of Projectile

Fig. 2. Projectile section and finite element model showing general location of high residual tensile stresses. 


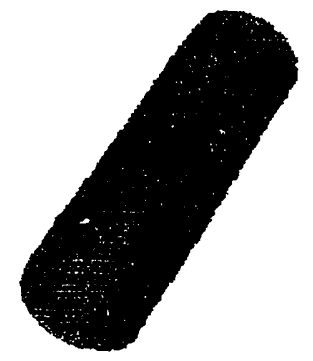

8
8
0
0
0
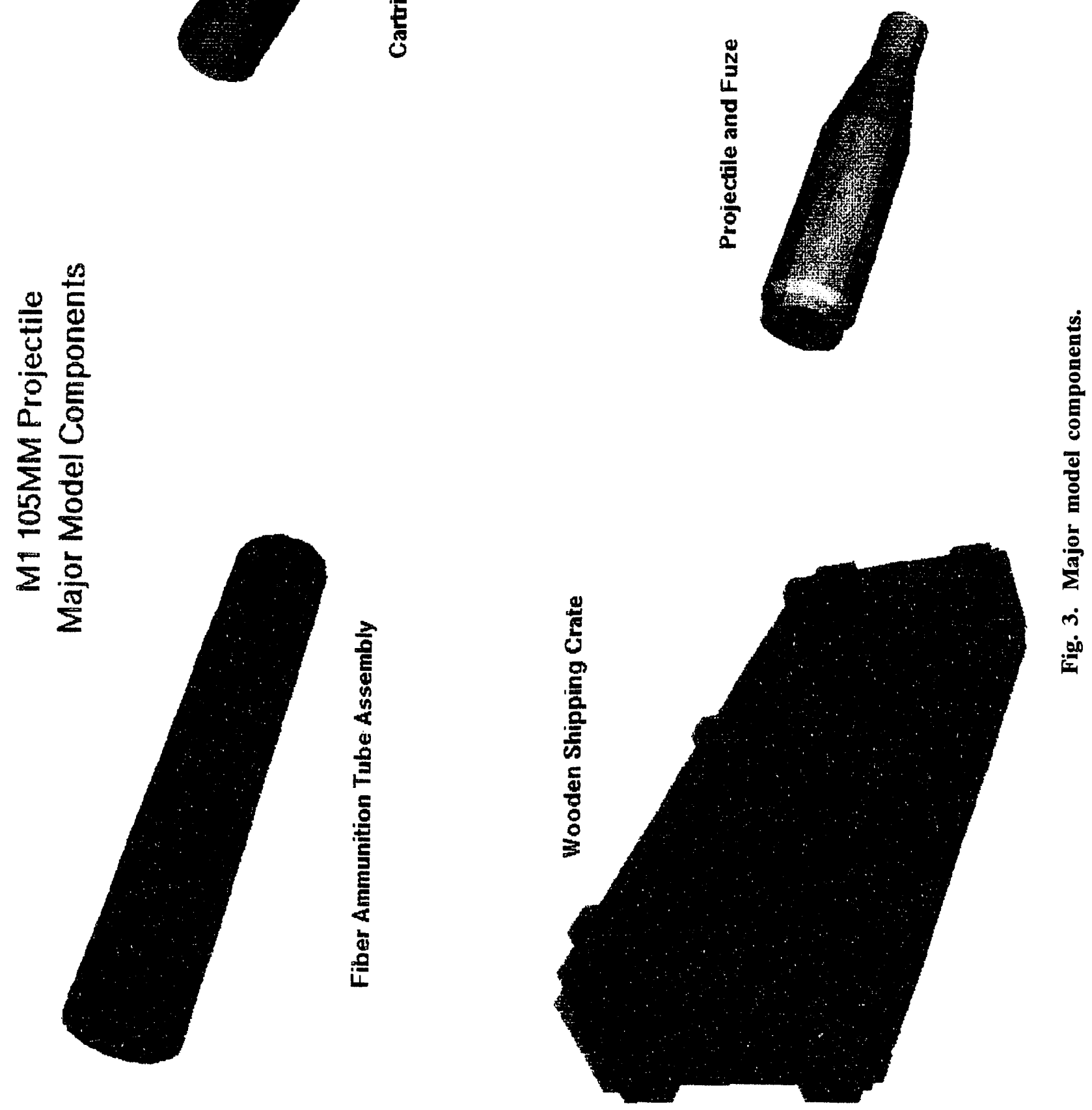

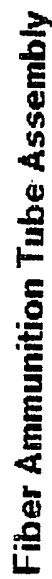




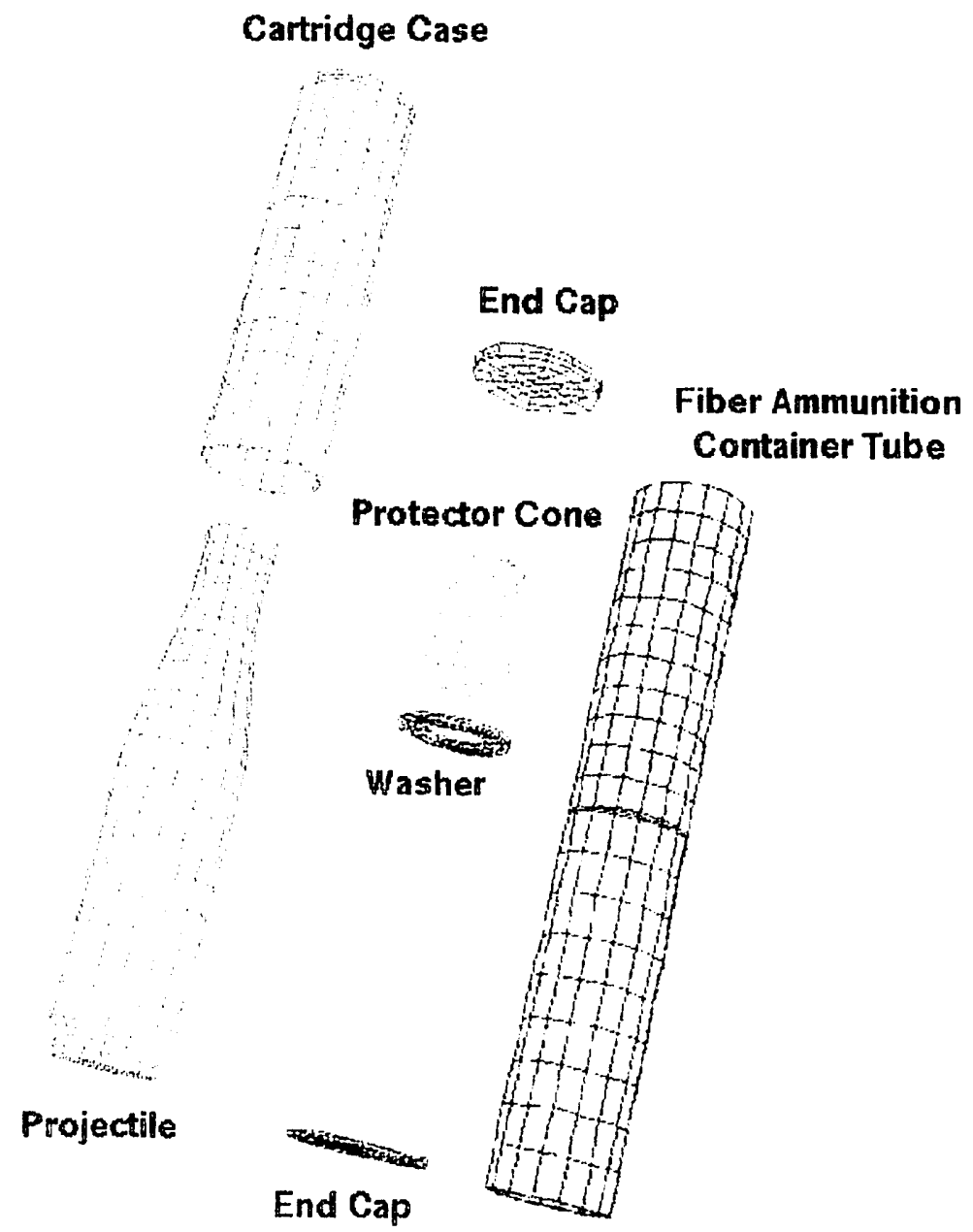

Fig. 4. Model components for the fiber ammunition tube drop cases. 


\section{M1 105MM Projectile \\ Complete Model}

\section{Shipping Crate \\ Top}

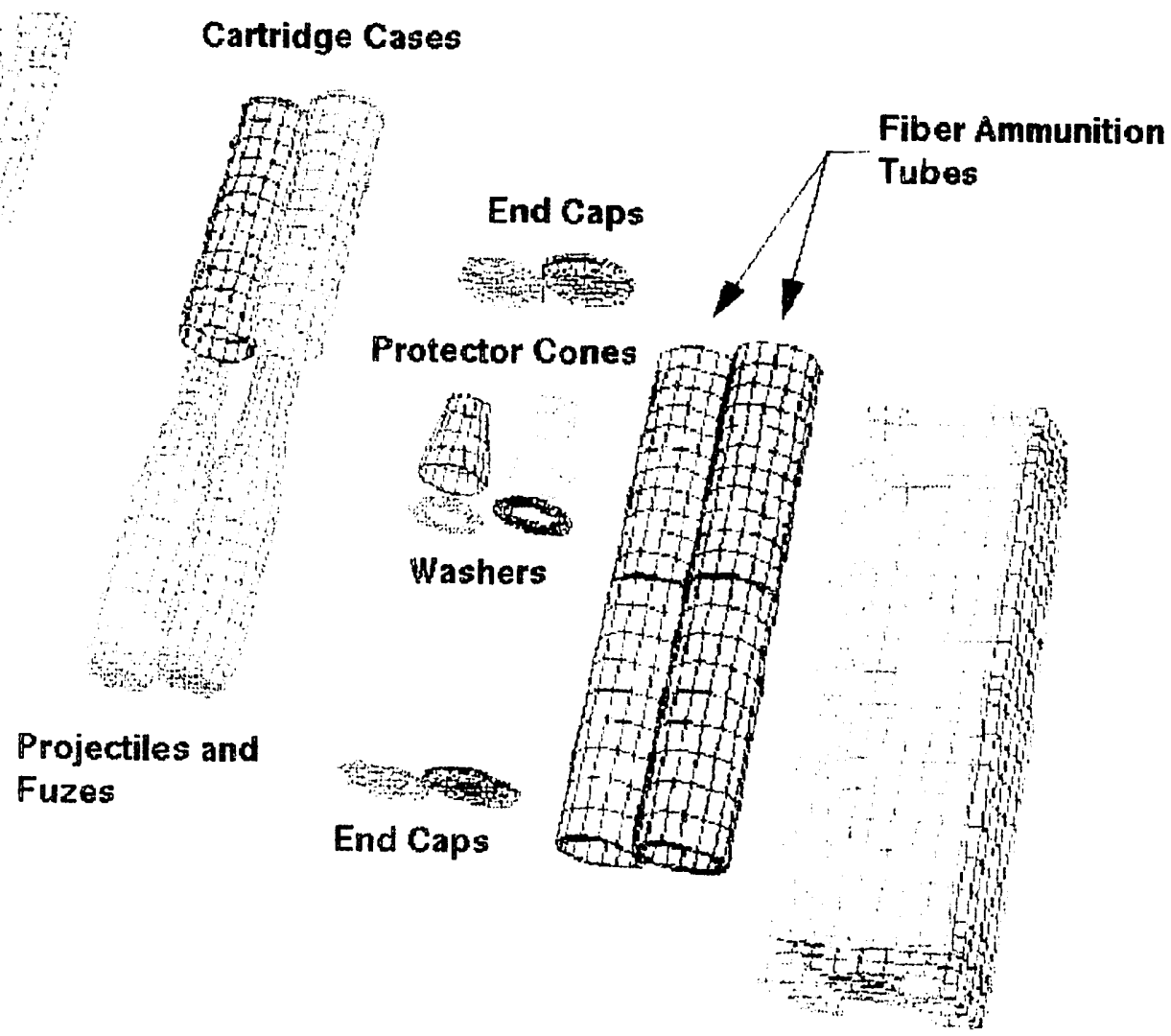

Wooden Shipping
Crate

Fig. 5. Model components for the fiber ammunition tube drop cases. 


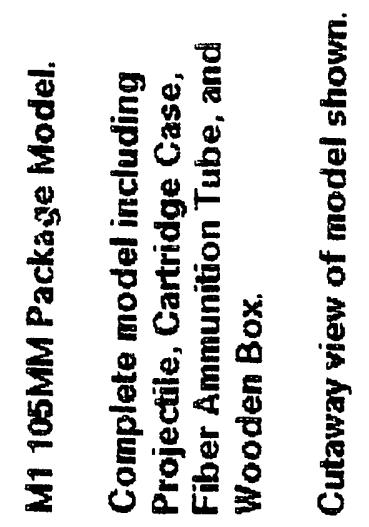

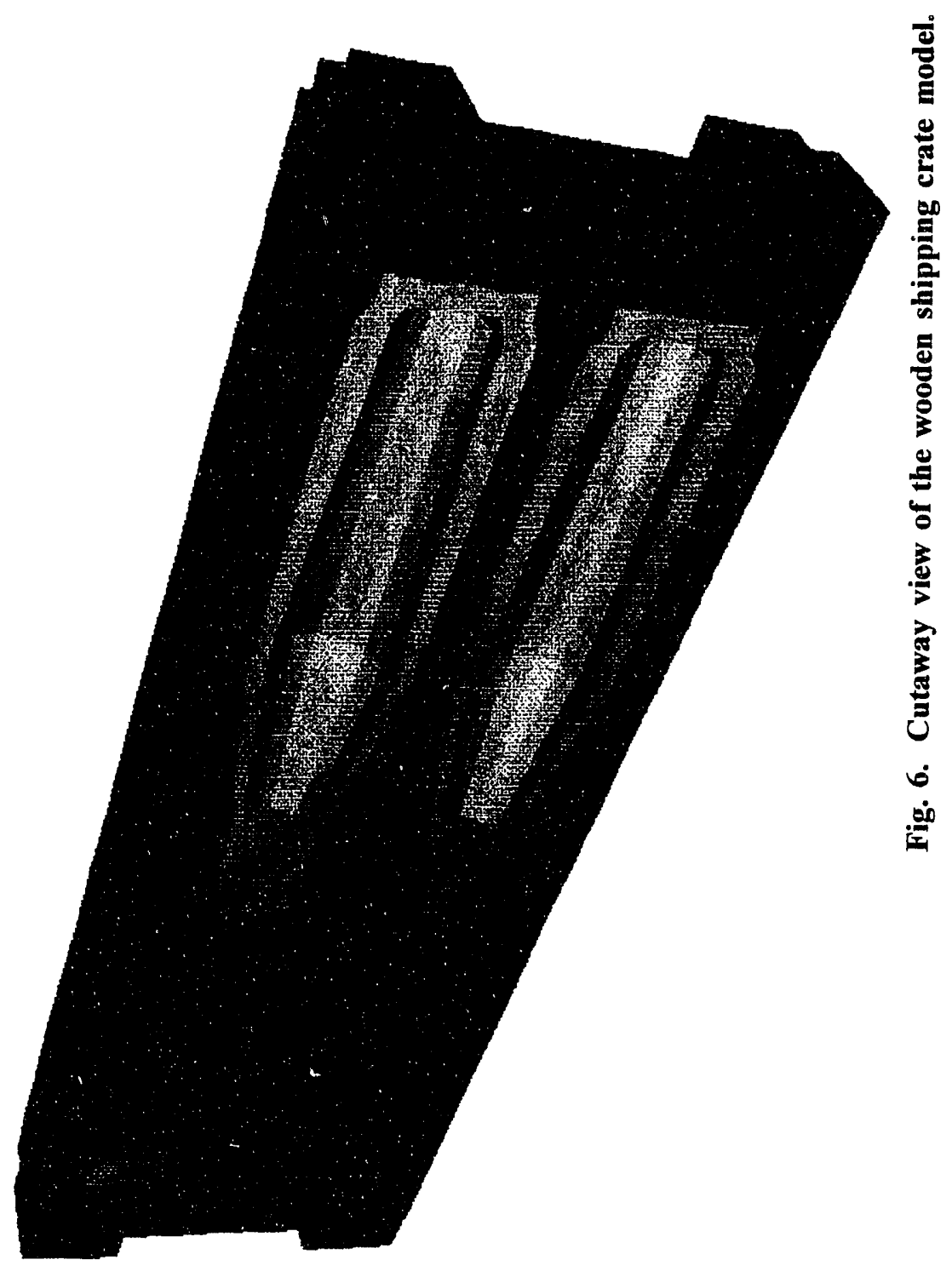



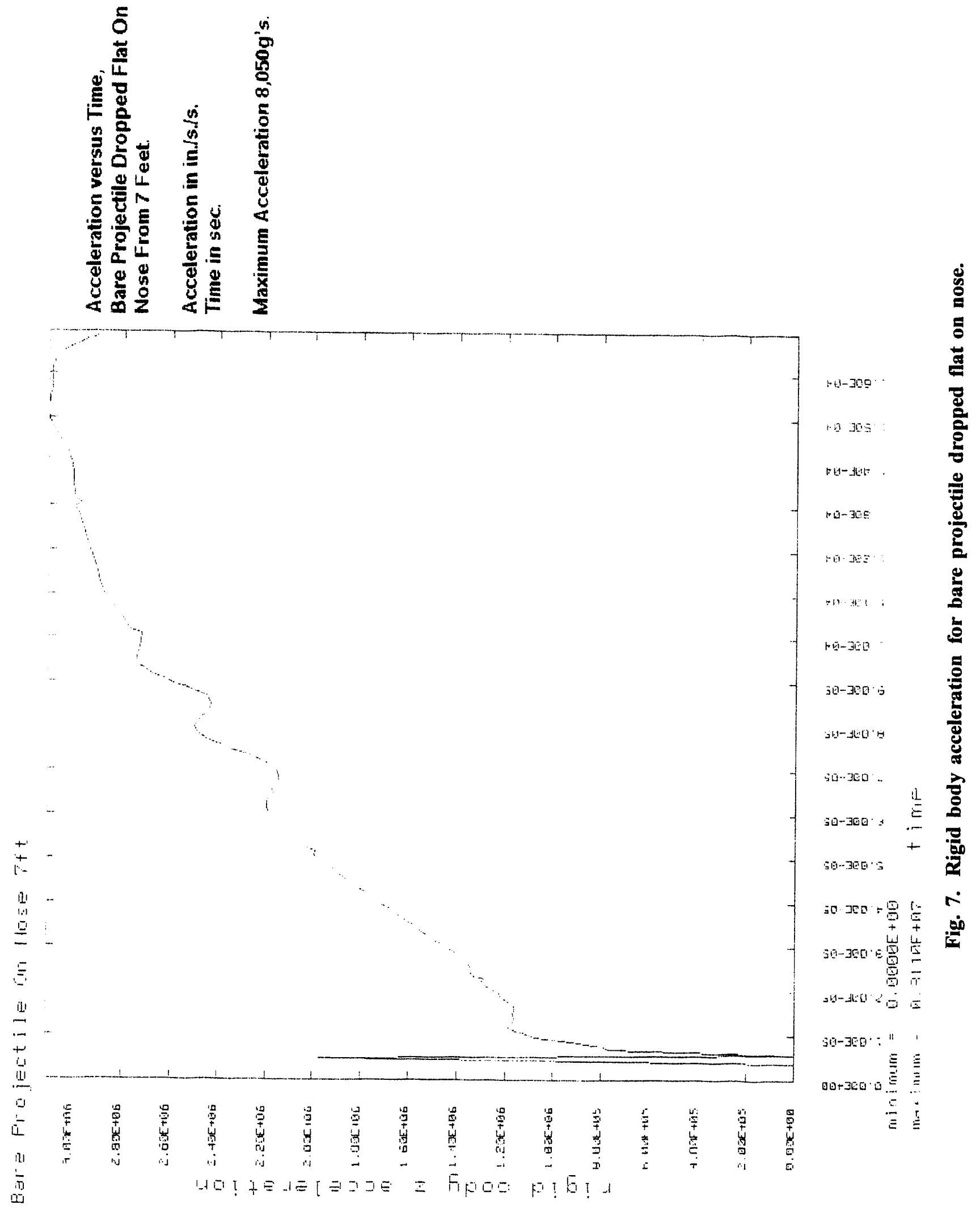
15

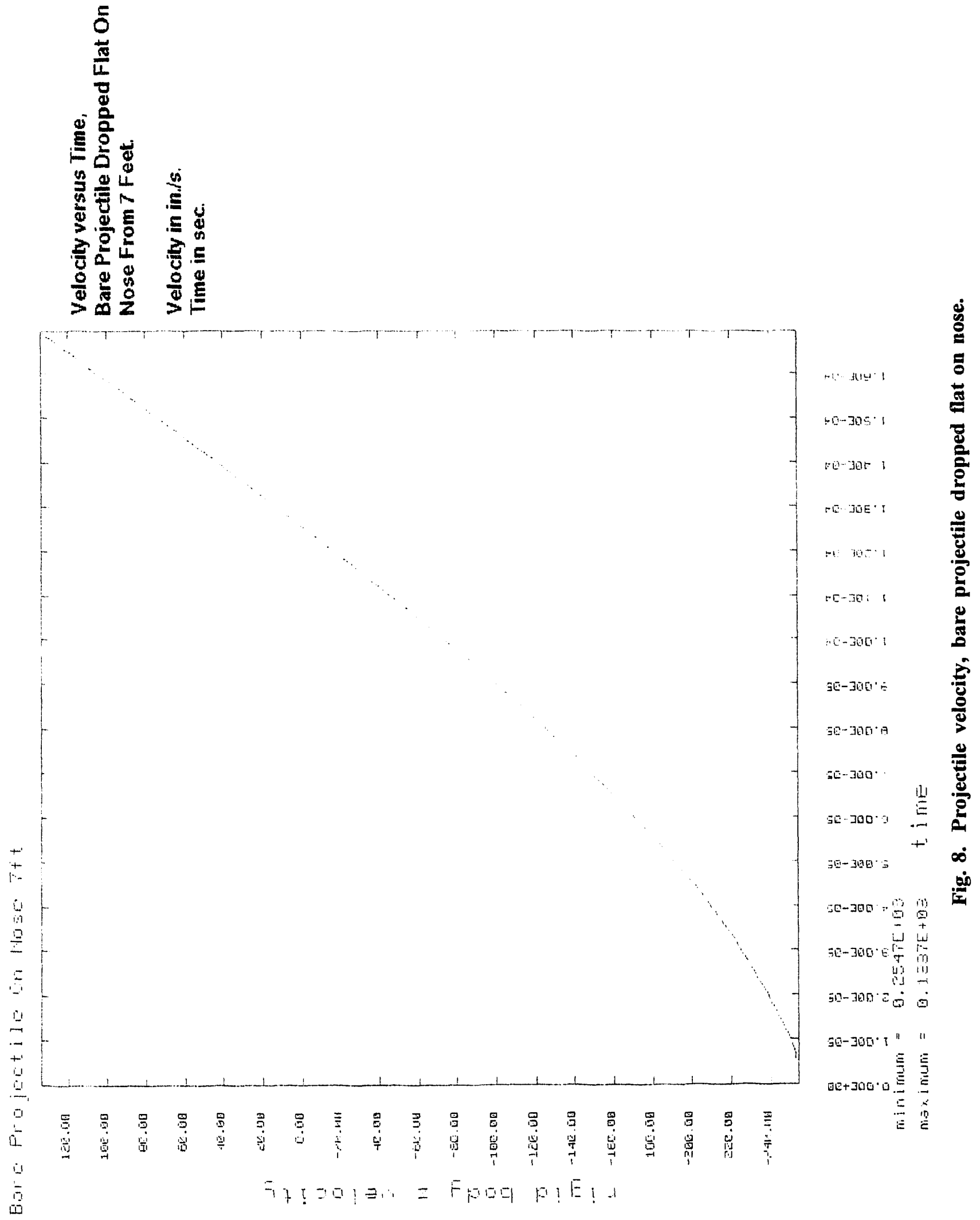



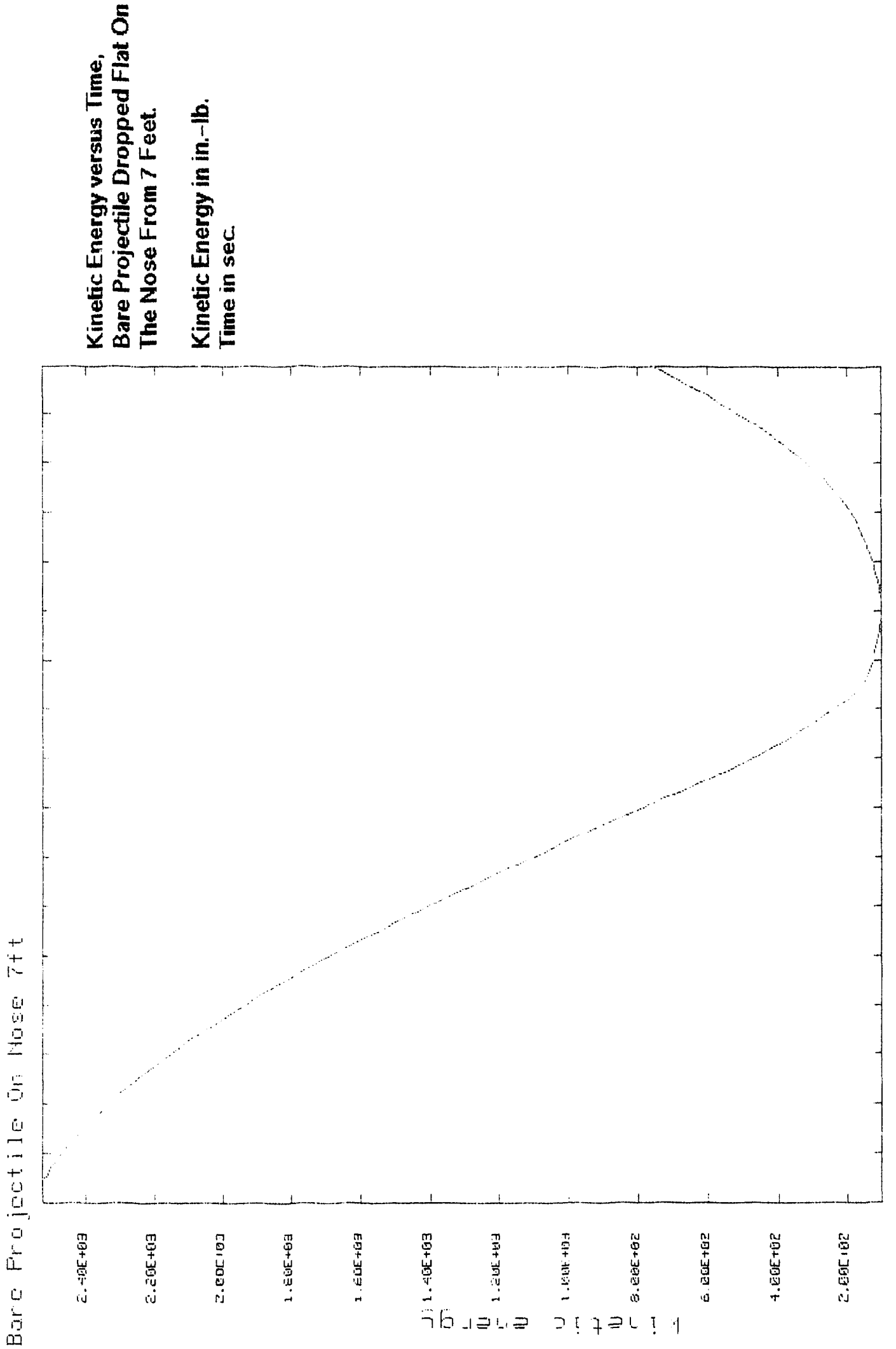

$+E-300 \cdot$

$-4-30: 1$

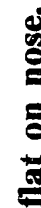

TE J日E. 1

DQ-3QE

$\rightarrow-39=1$

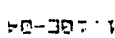

$+0-360 \cdot$

(a)

ริ-300.

SE. $786 \cdot 0$

50-300:

00-300.3

$30-700 \cdot 3$

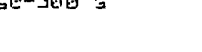

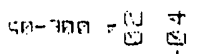

$30-300 \cdot 6 \stackrel{4}{\frac{4}{2}}$ 其

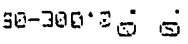

ร6-3 $360 \cdot 6 " 11$

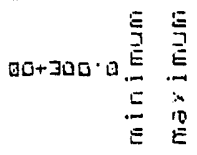



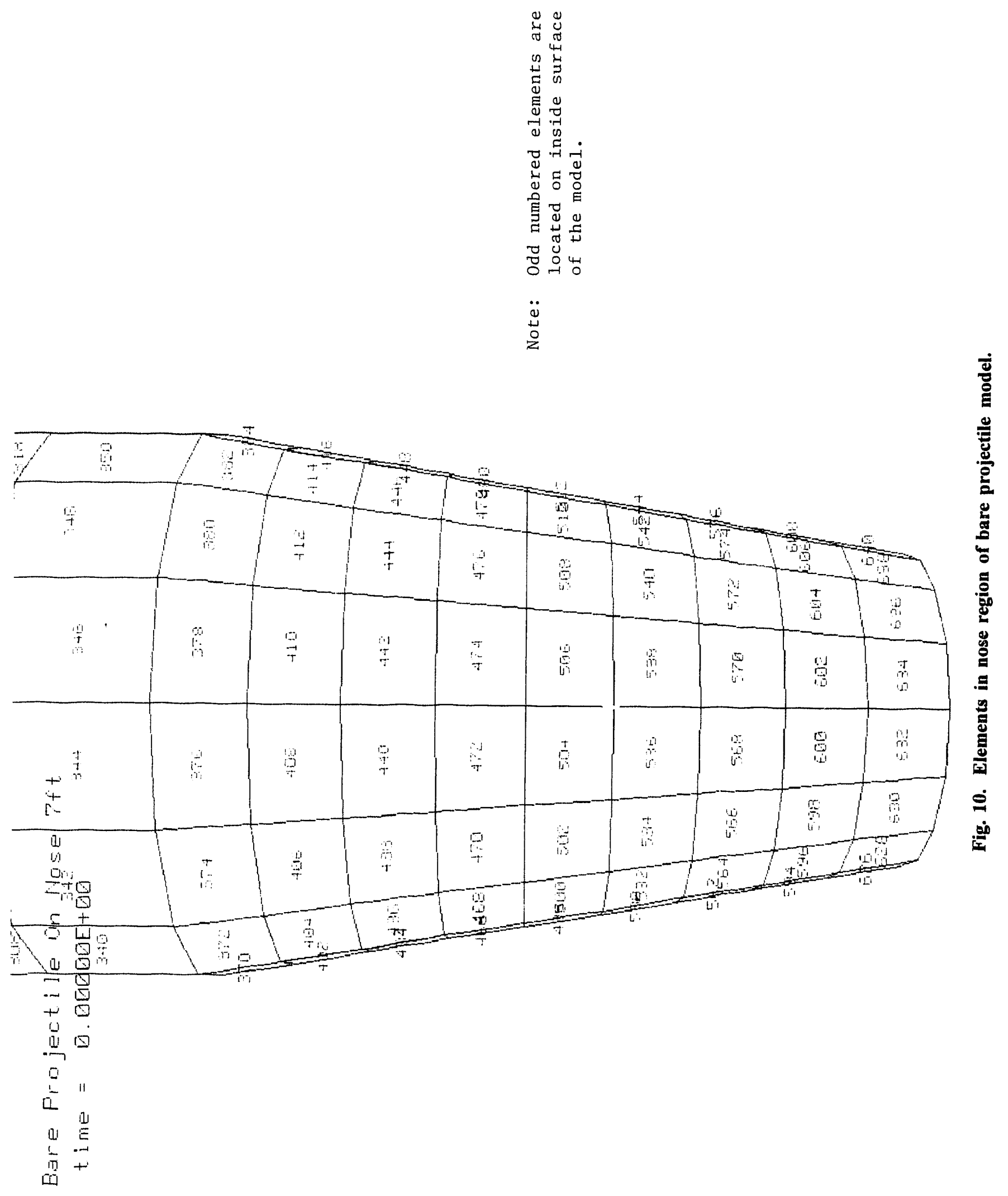


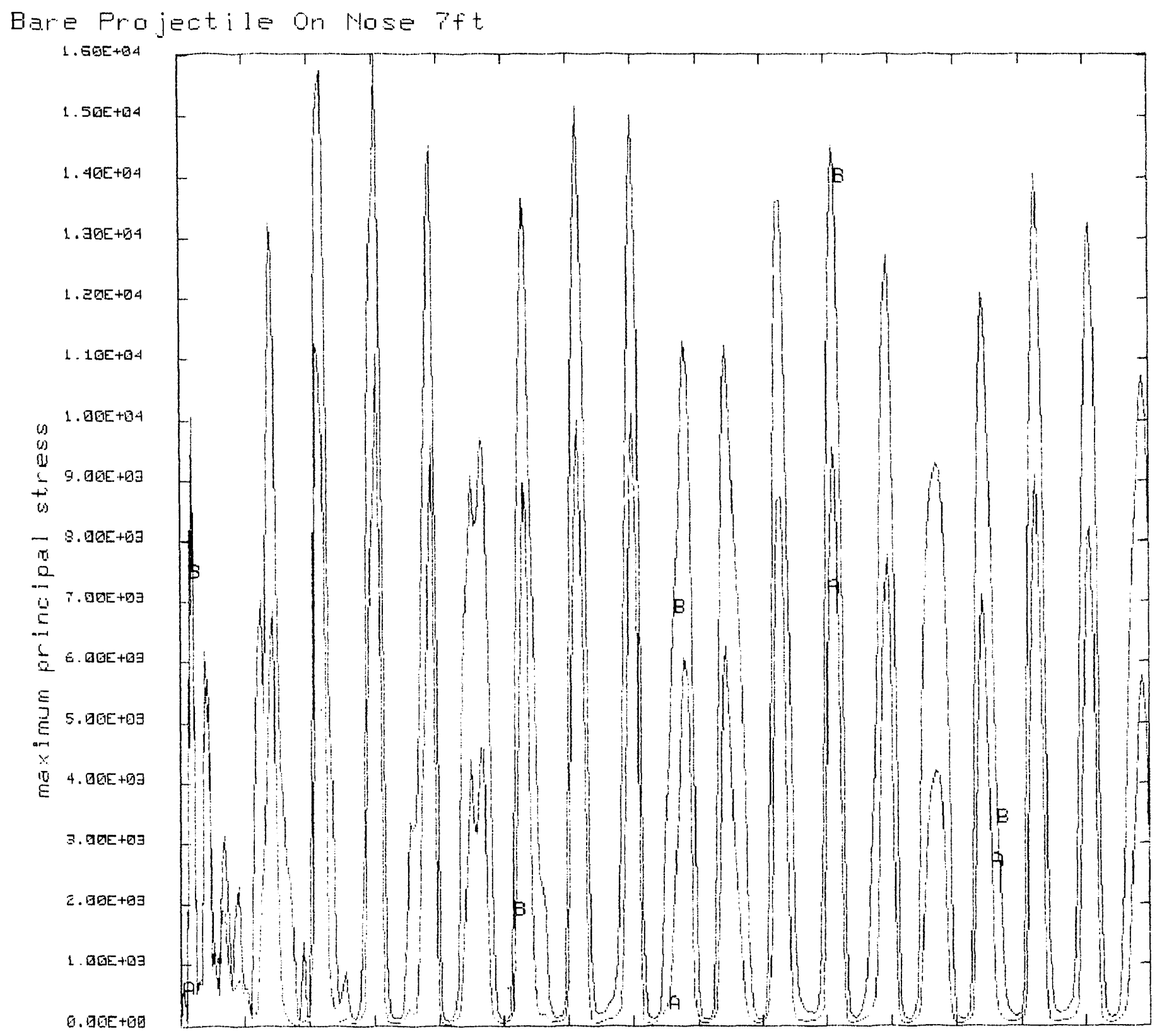

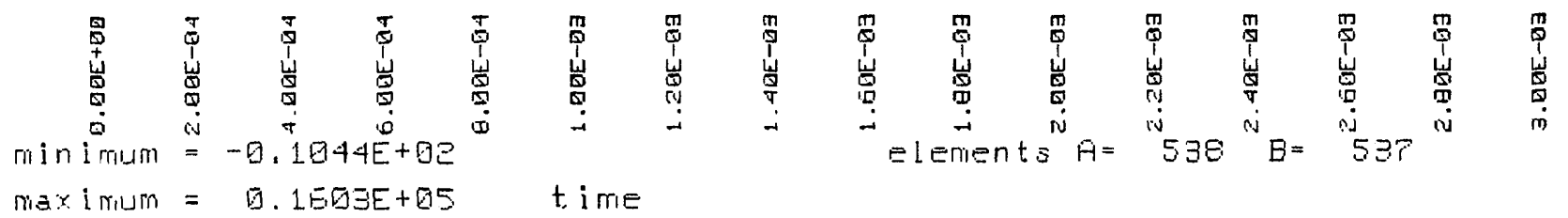

Fig. 11. Time history of maximum principal stress in elements 537 and 538. 
Bare Projectile On Mose $7 f t$

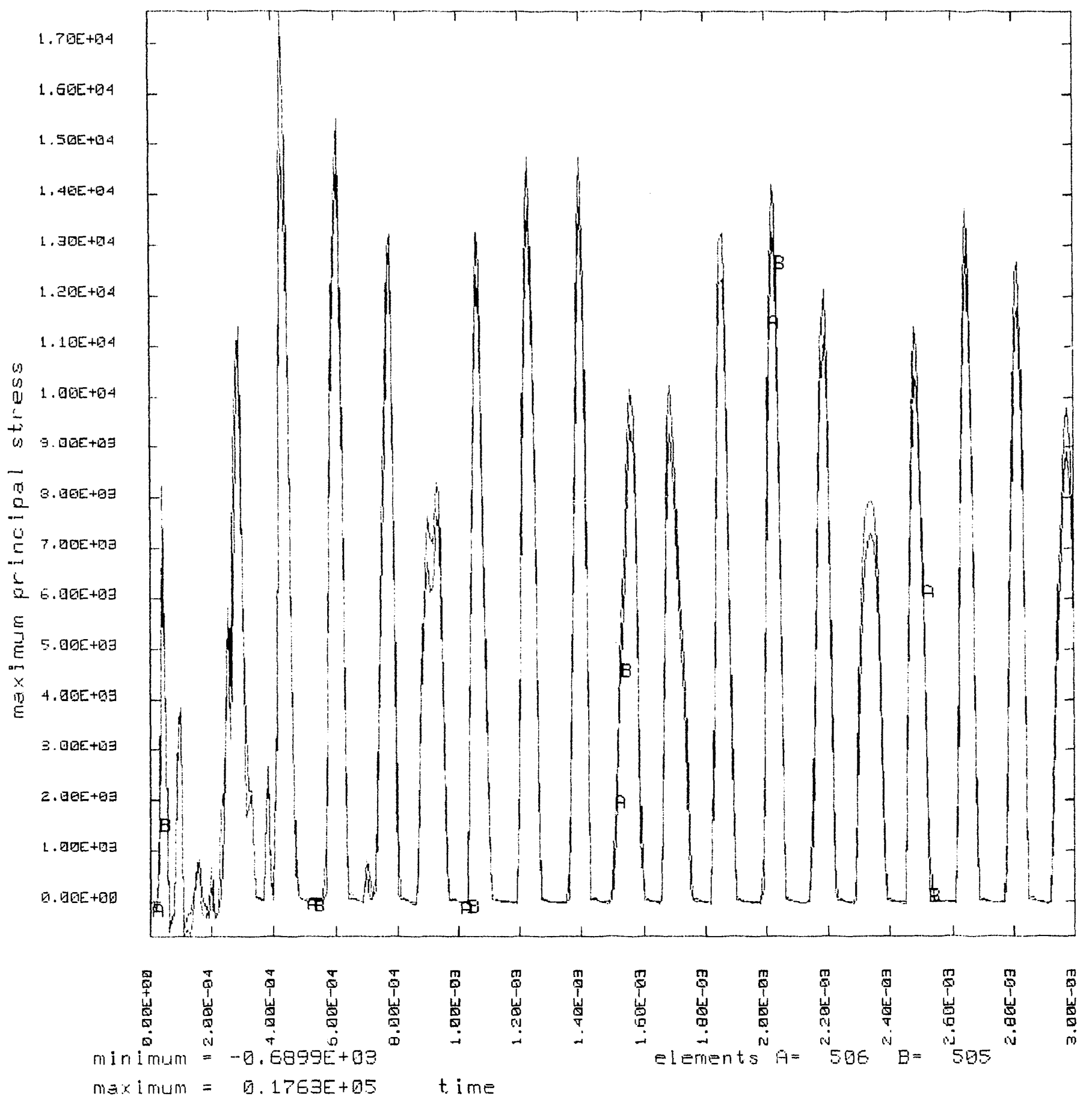

Fig. 12. Time history of maximum principal stress in elements 505 and 506. 


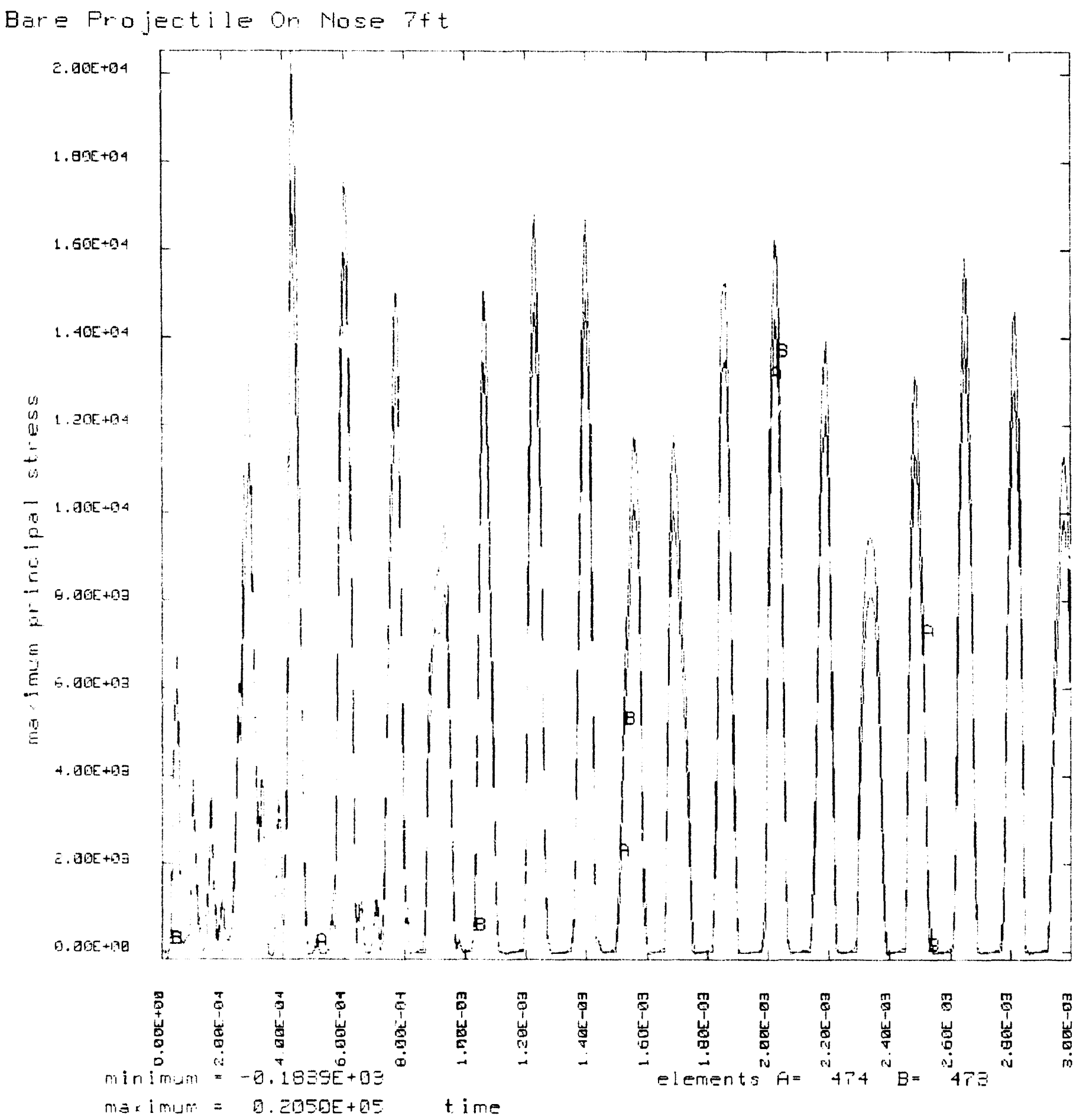

Fig. 13. Time history of maximum principal stress in elements 473 and 474. 


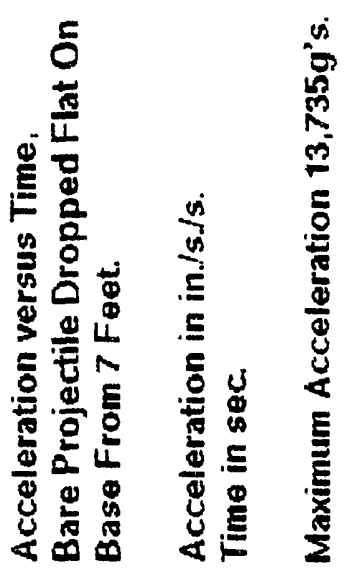

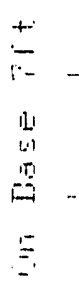
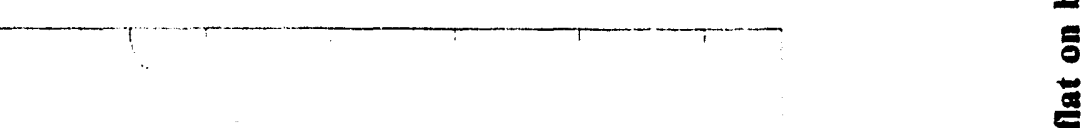

THE
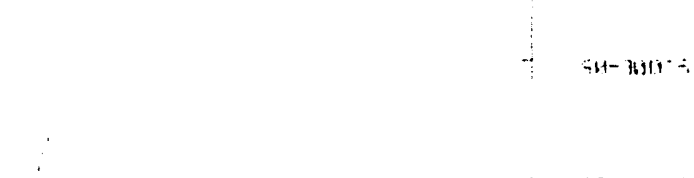

$\therefore 6-305 \div=$
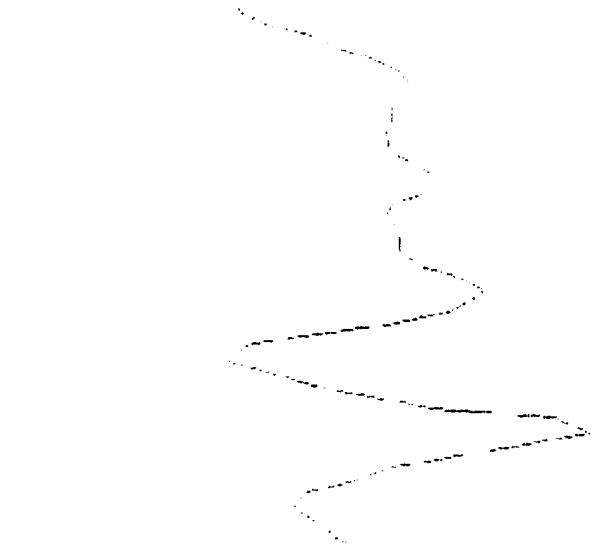

$=196$

กิ
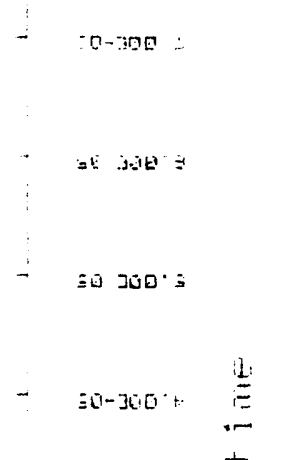

gू

흘

홍

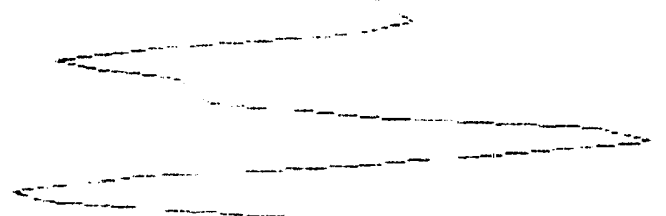

$\therefore \quad 30100$

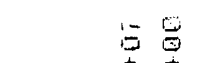

- 9 -300 湍崖
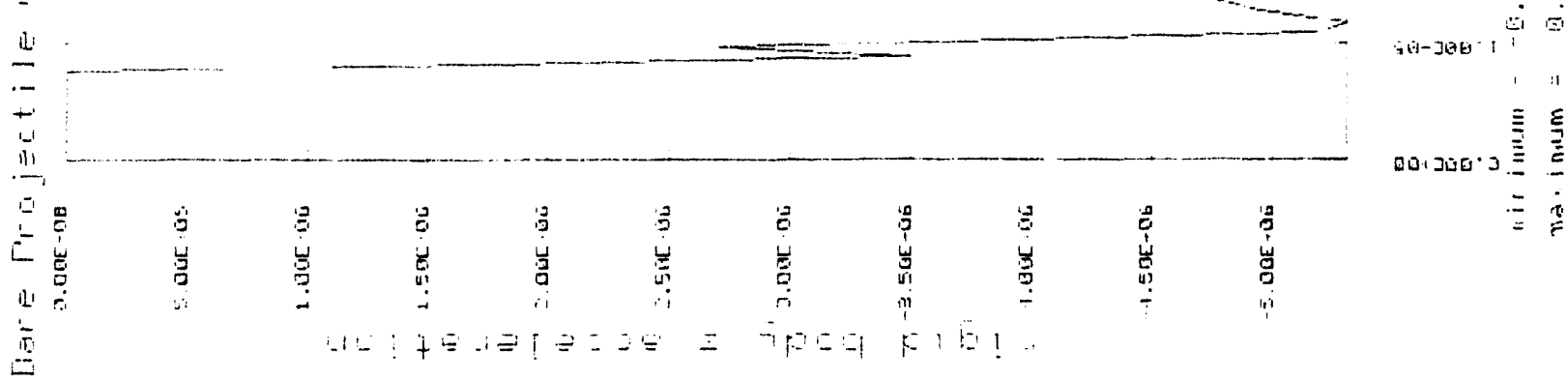

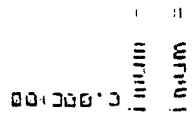

를 
Bare Projectile On Base Pft

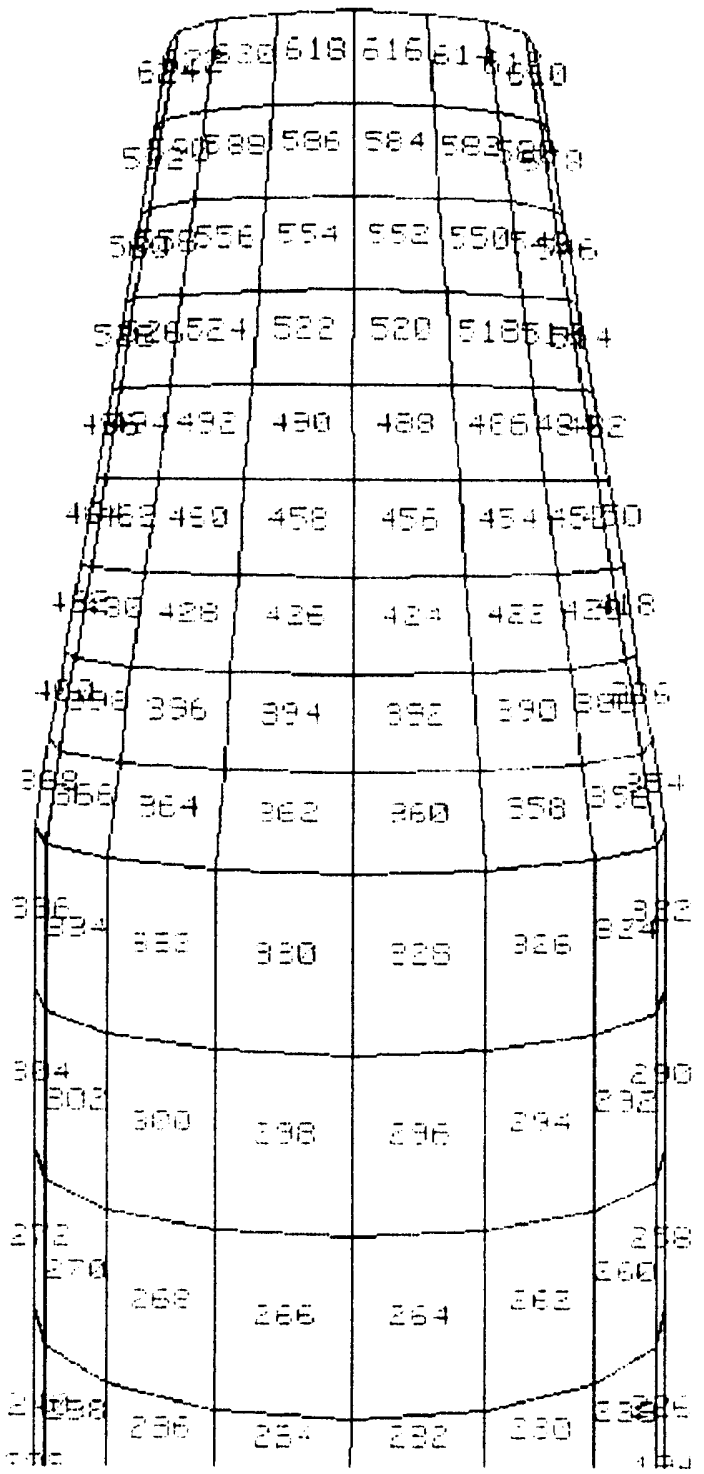

Fig. 15. Element numbers in nose region of model. 


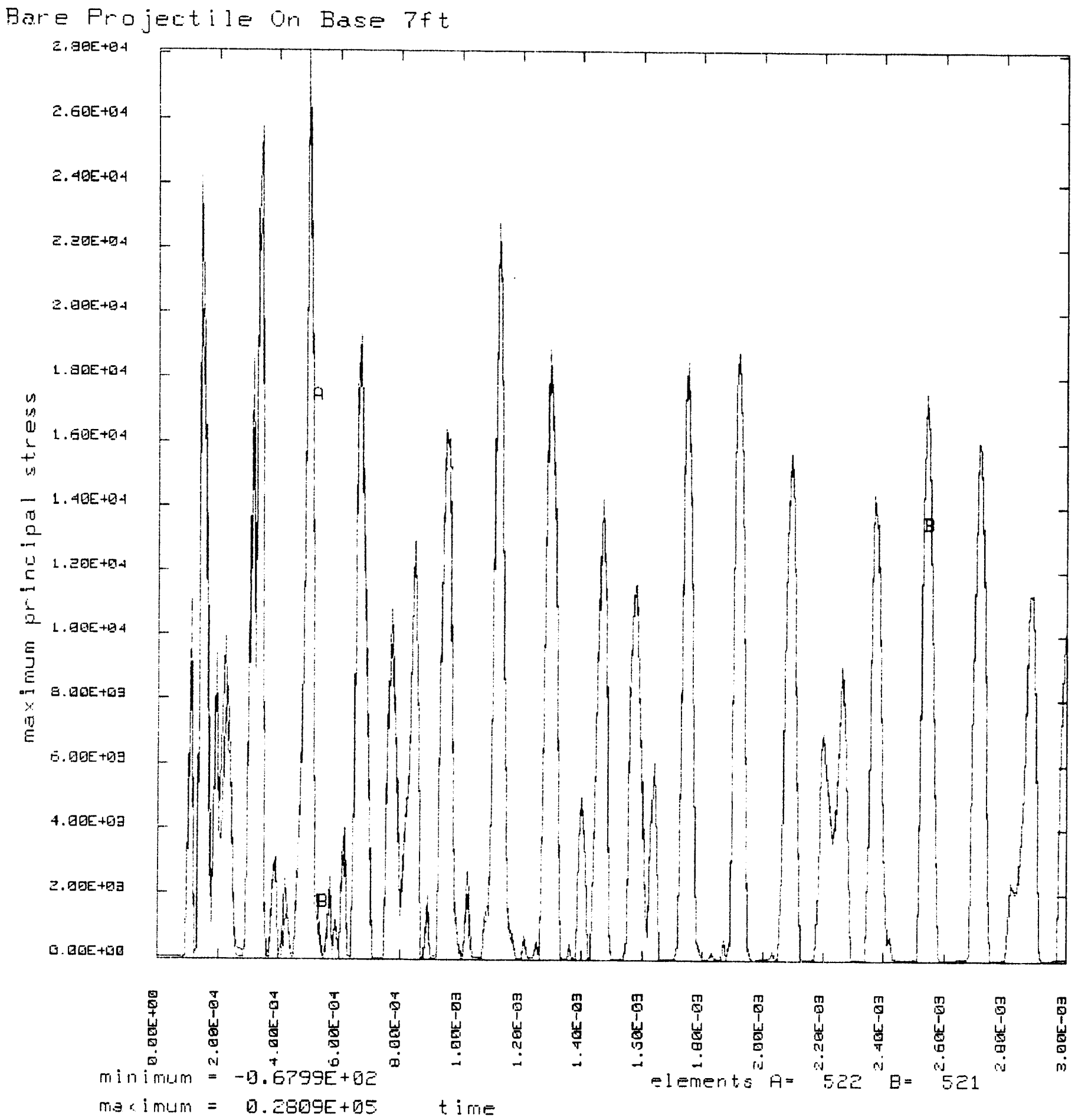

Fig. 16. Time history of maximum principal stress in elements 521 and 522 . 
Bare Projectile Or Base ift

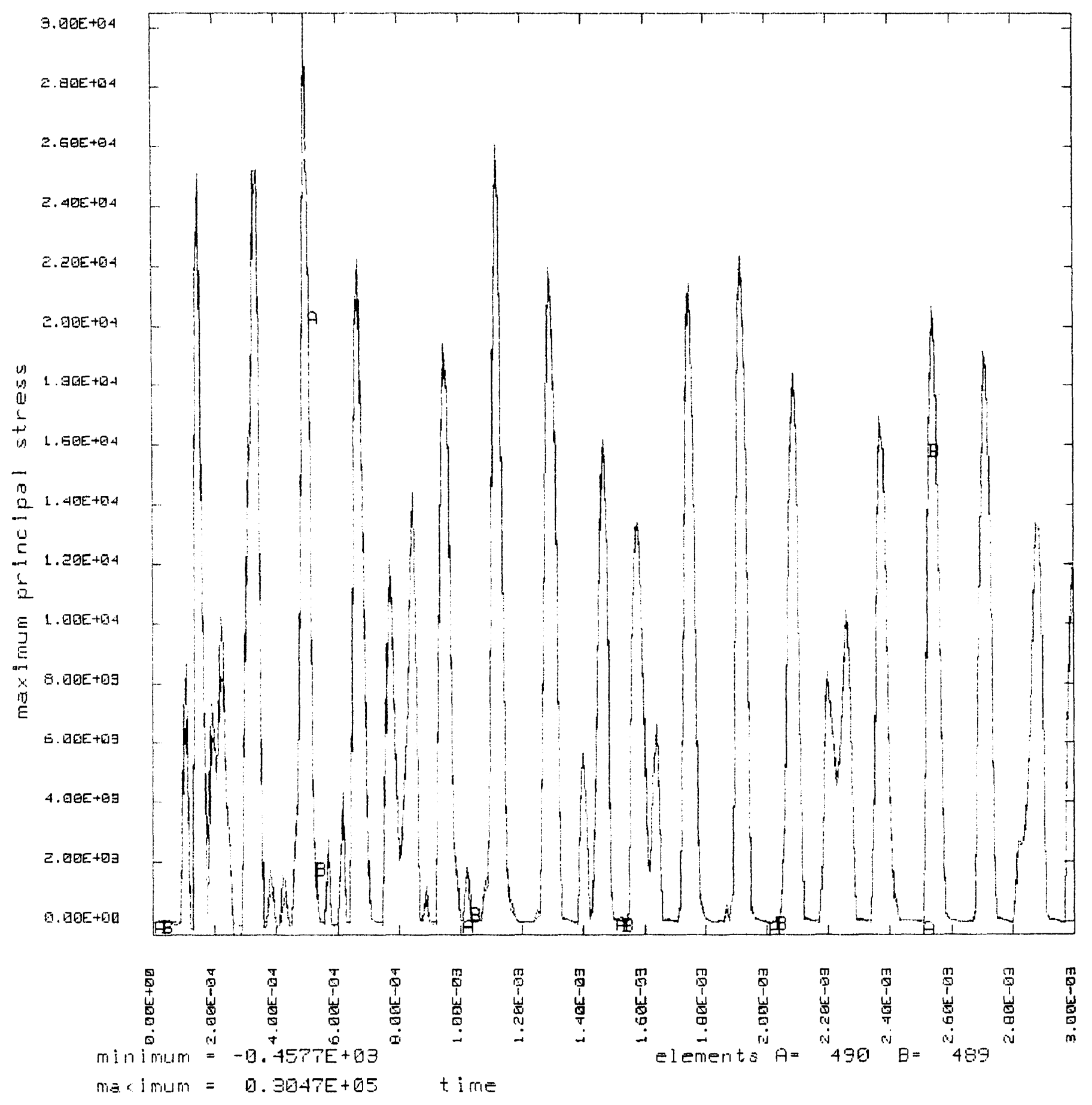

Fig. 17. Time history of maximum principal stress in elements 489 and 490. 


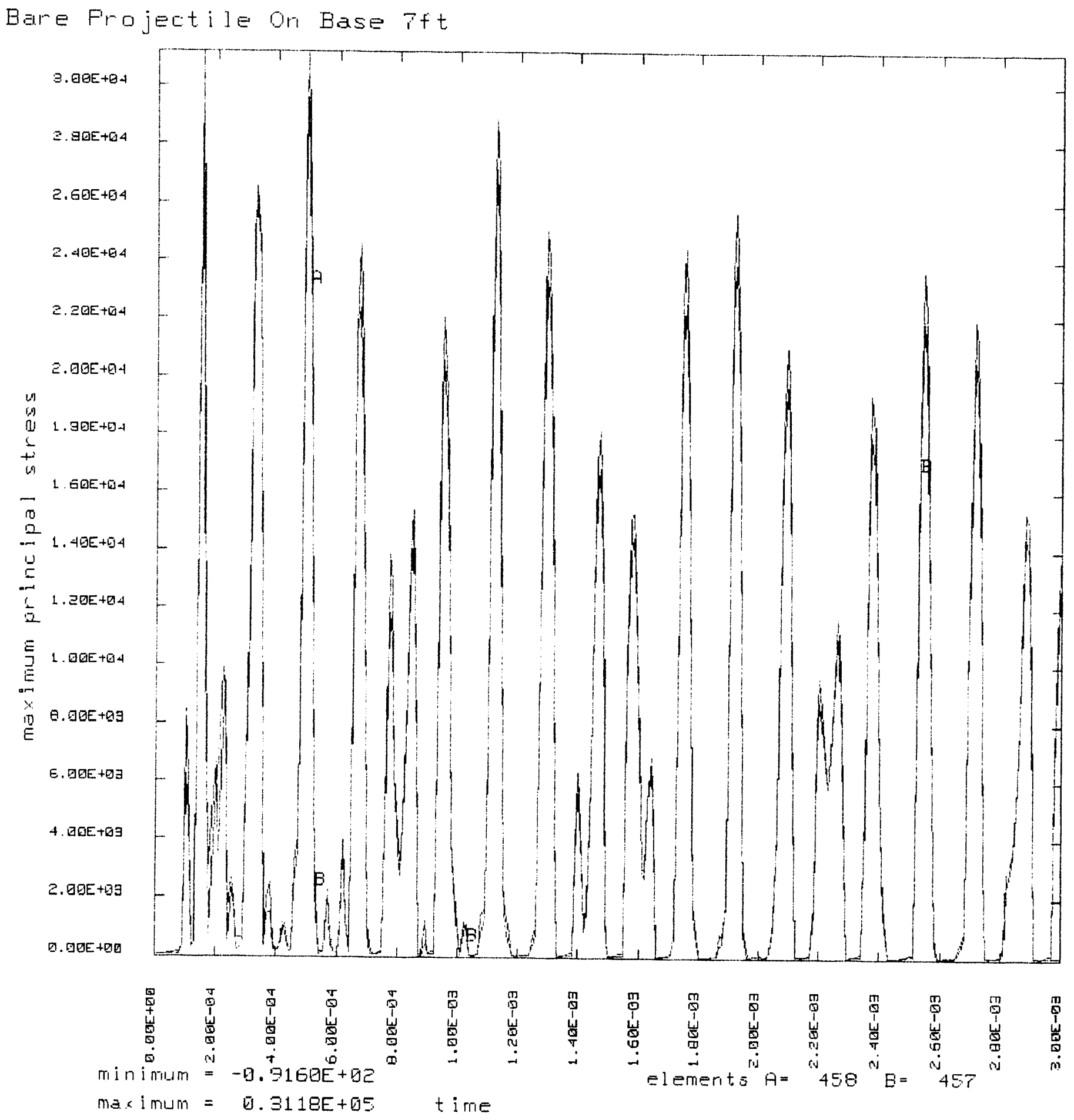

Fig. 18. Time history of maximum principal stress in elements 457 and 458. 

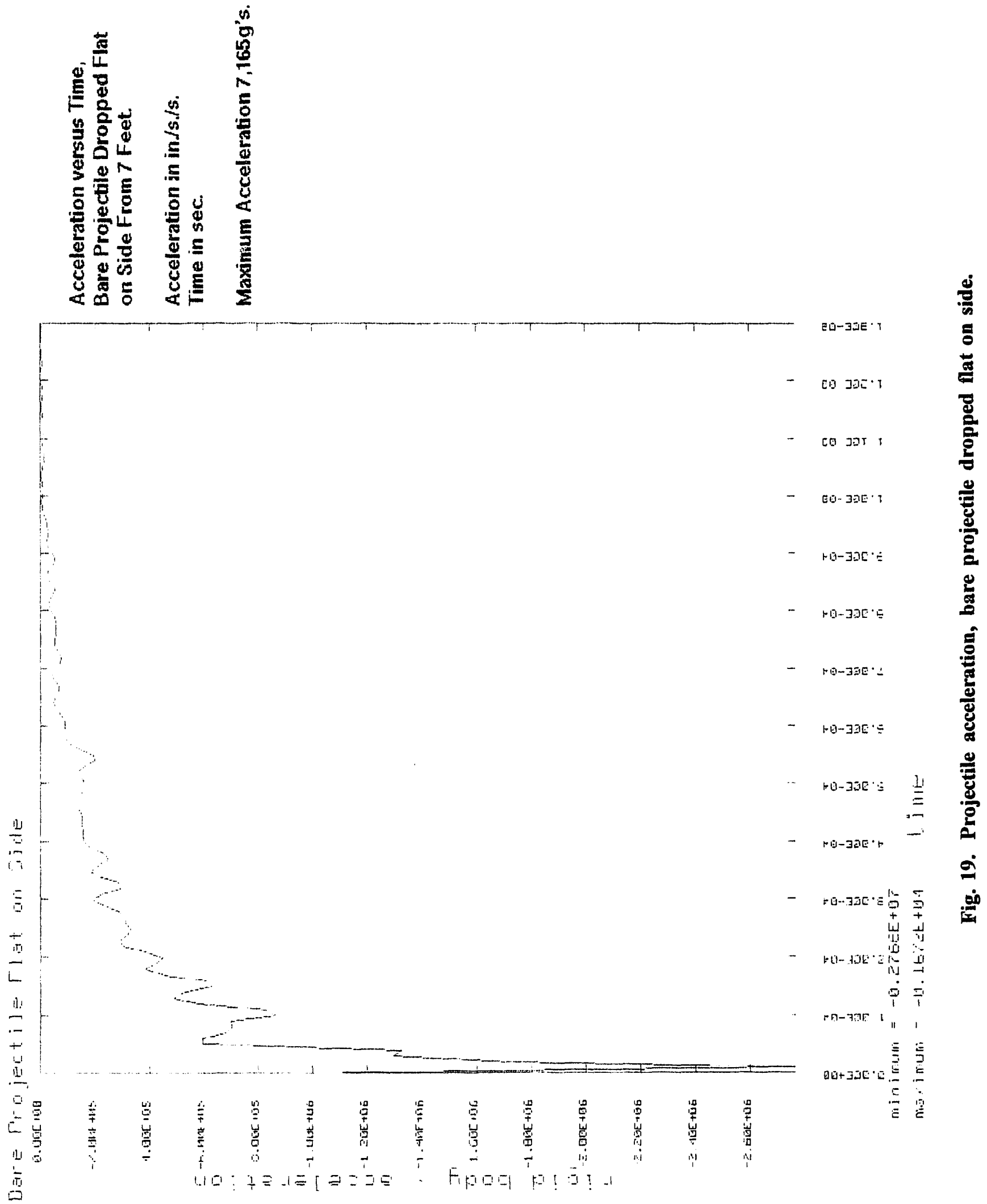
Bare Frojectile On Hose at 45

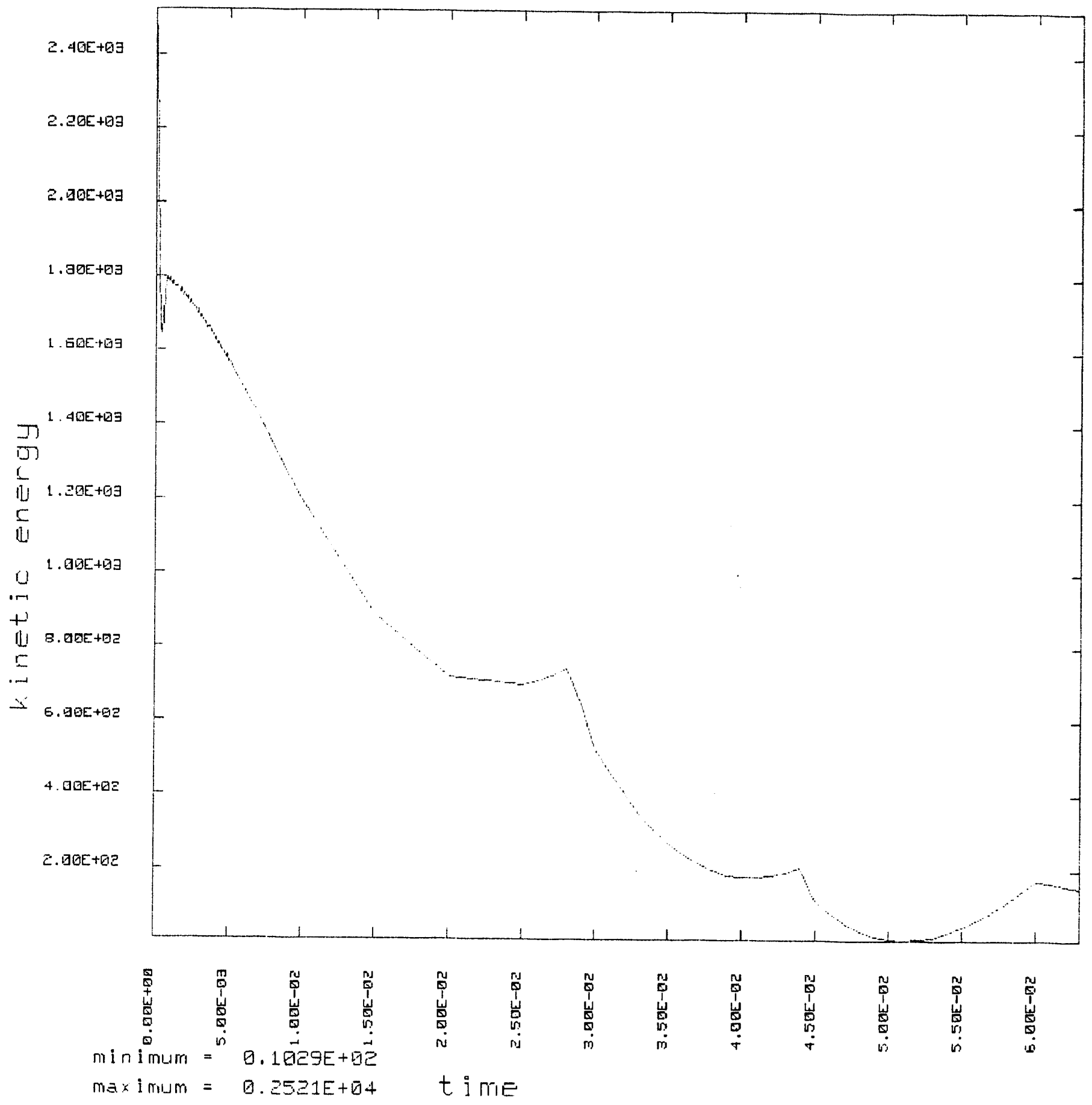

Fig. 20. Kinetic energy vs time for bare projectile impacting at $45^{\circ}$. 


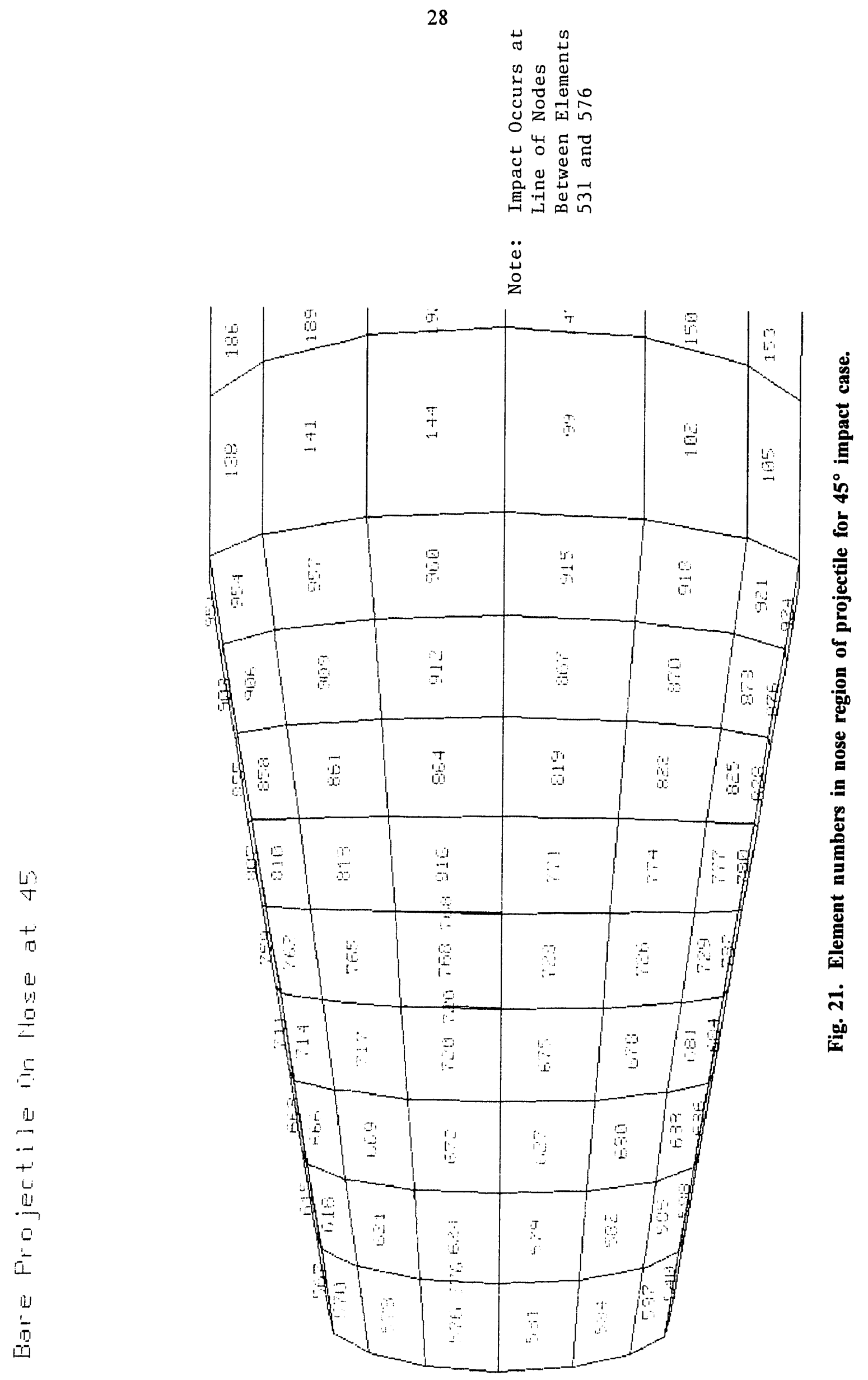


Bare Projectile Dn Mose at 45

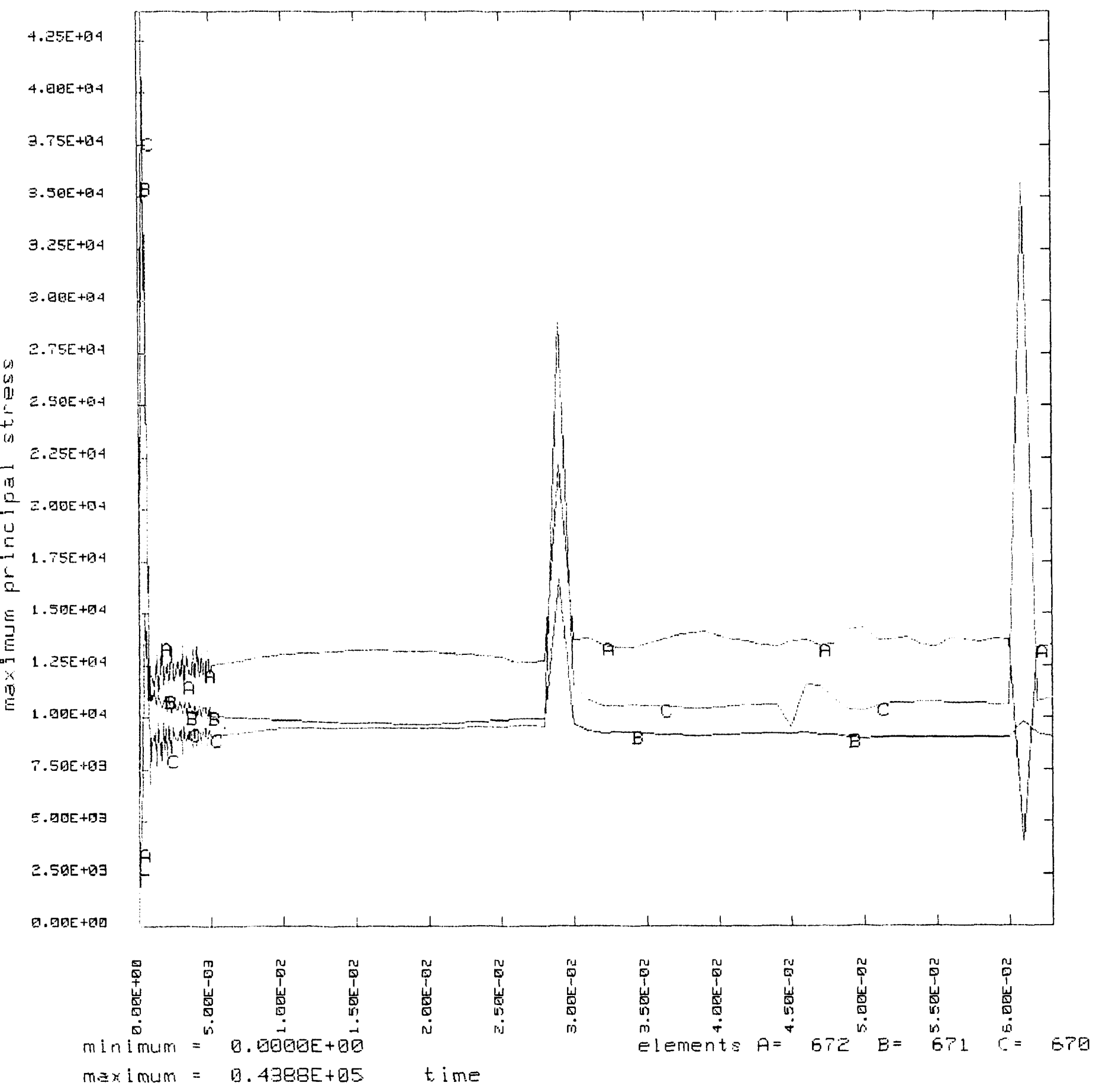

Fig. 22. Time history of maximum principal stress for elements 670-672. 
Bare Frojectile On Wase at 45

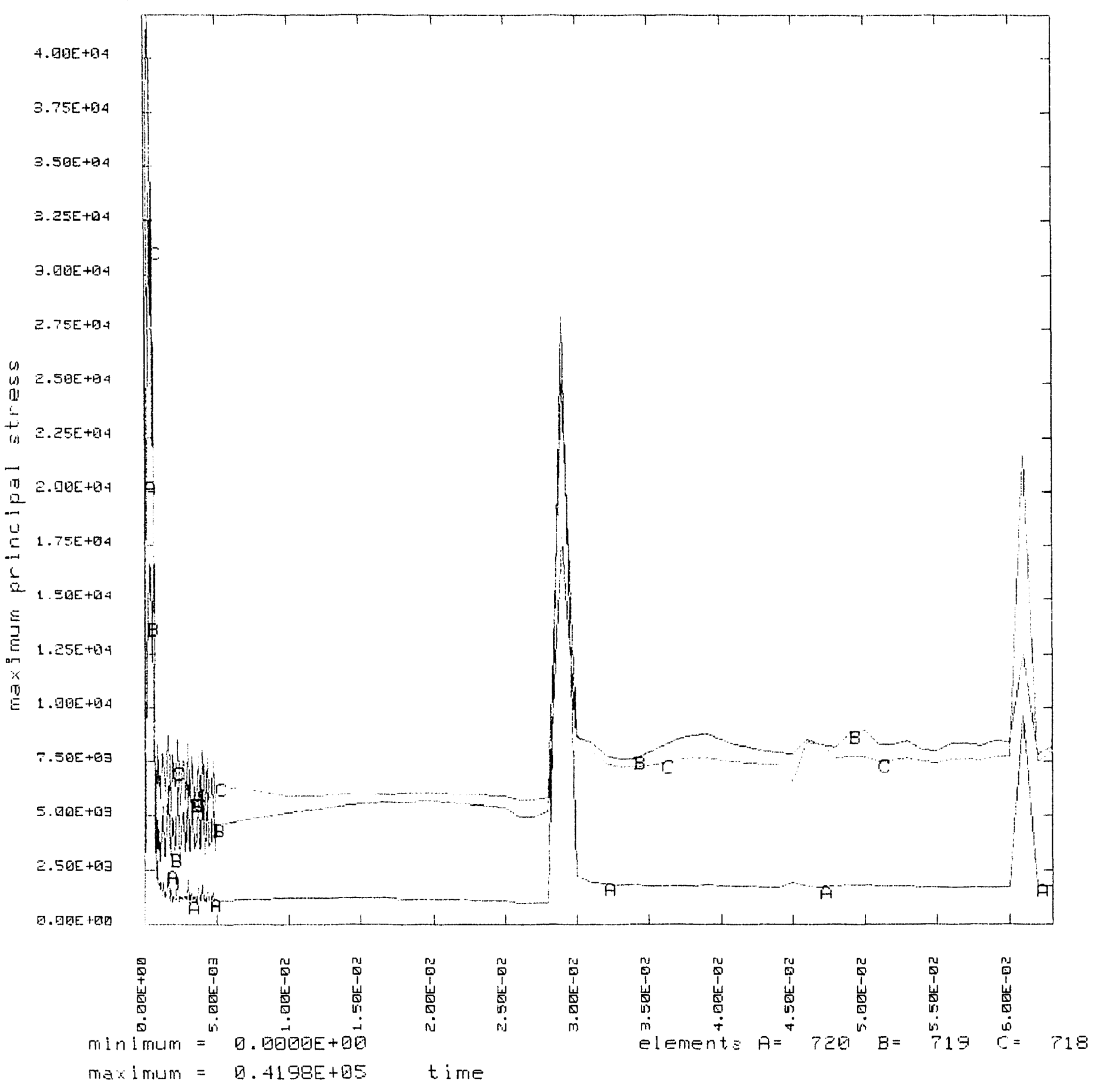

Fig. 23. Time history of maximum principal stress for elements 718-720. 
Bare Frojectile Dn wose at 45

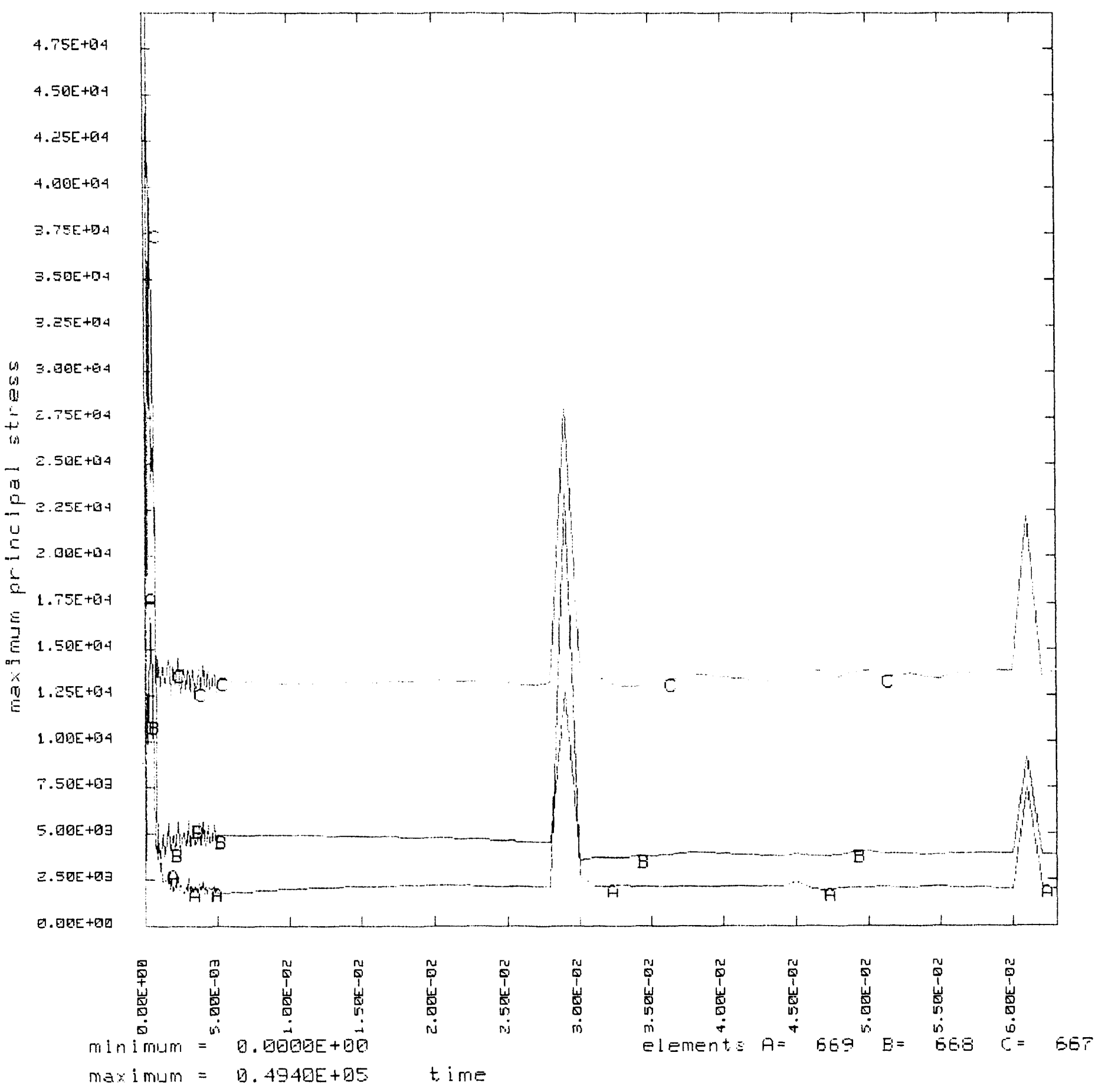

Fig. 24. Time history of maximum principal stress for elements 667-669. 

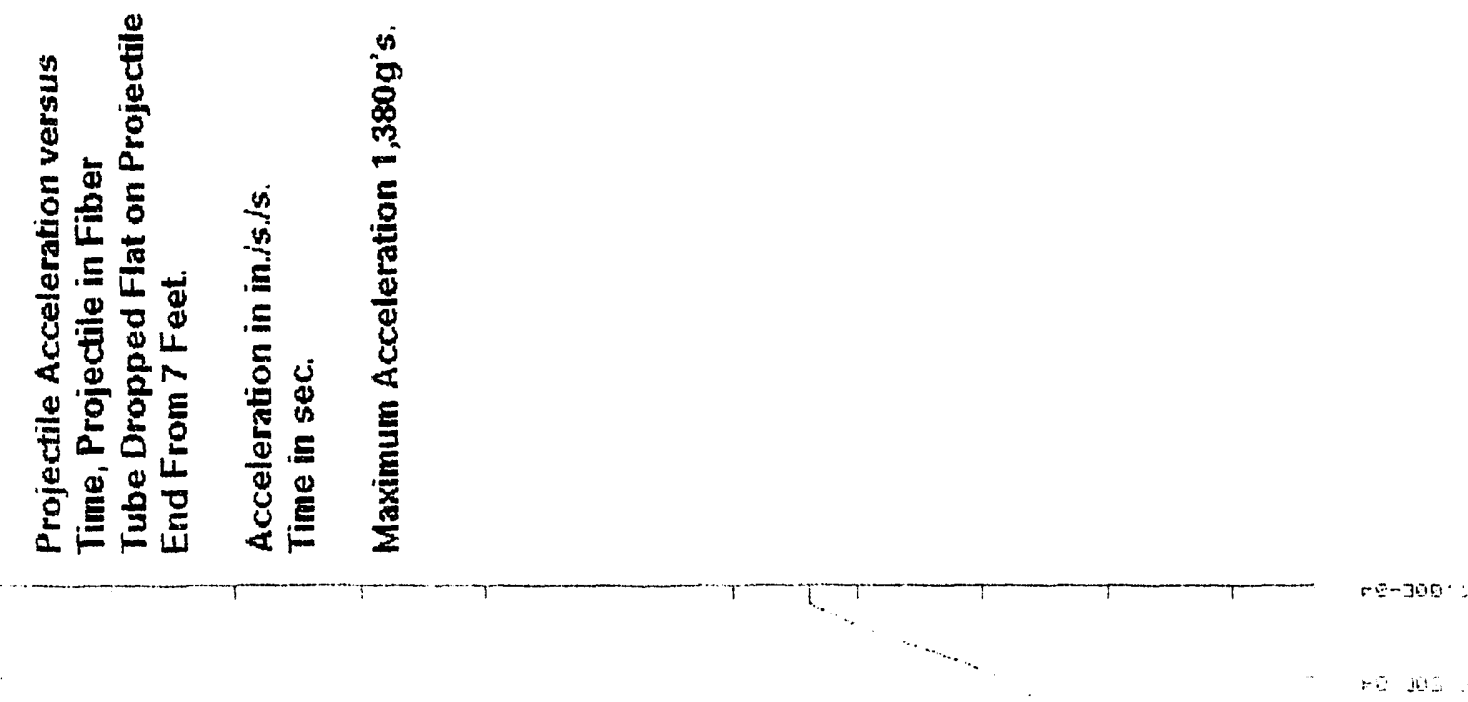

$-100=$

$5 F-7 w$

FE- $300 \cdot 51$

1. $-305+=$

$-2-300+\frac{L}{\underline{L}}$

$+1-j u s=$
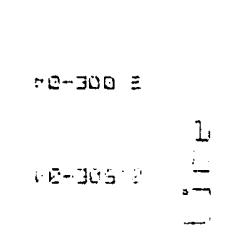

-[I-JU0.

$\rightarrow$

H[-]05.

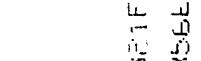

b L. Jus it: I

ثं

- $3 \mathrm{~A}^{-300 \%}$ 

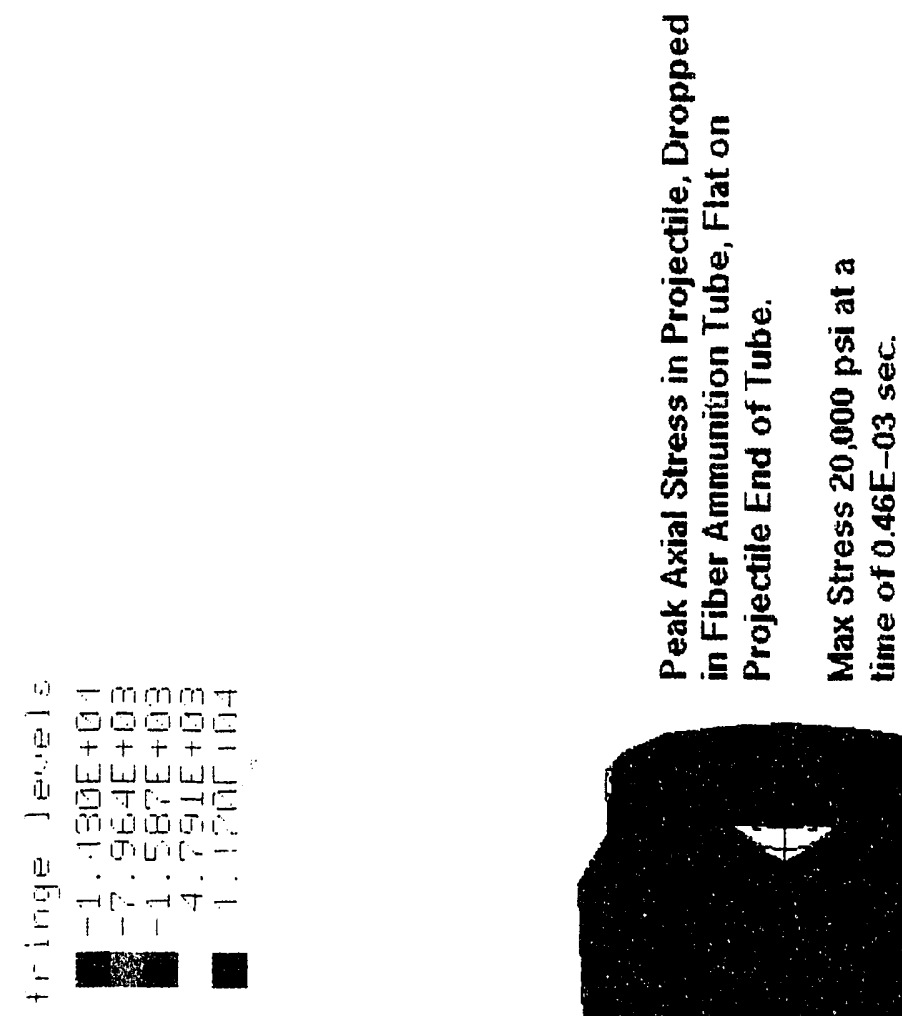

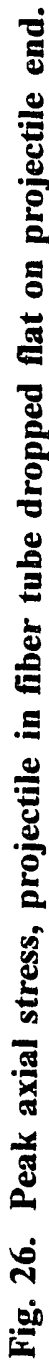



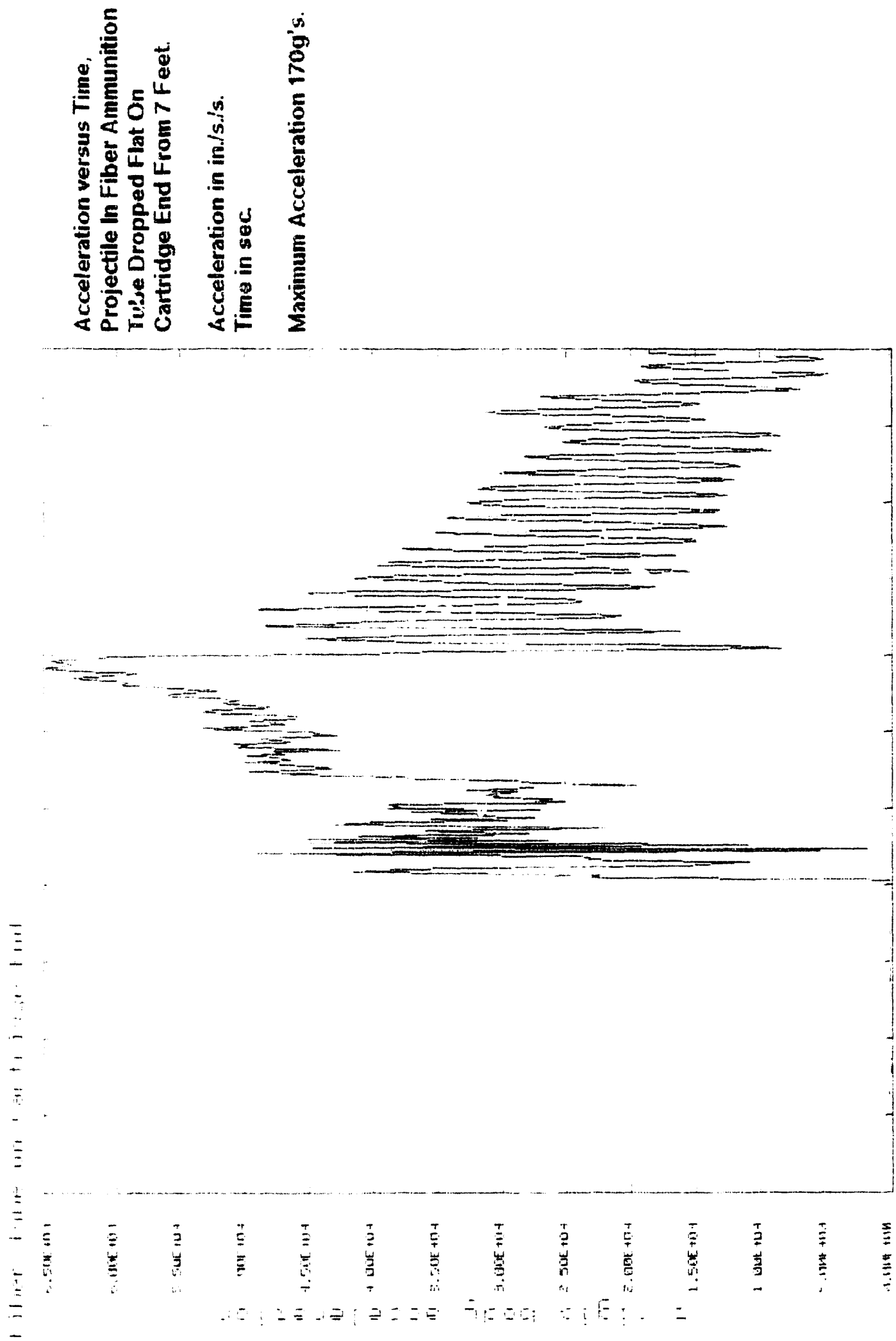

aอ-30

ลอ-3งต.

EO-300.5

하

Eแ-

EO- $300 \cdot=\frac{.}{2}$

竞

EO-300.3 $=$

흘

80-300: =

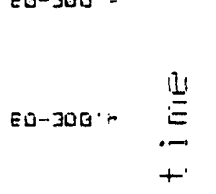

$54-305:$

$m$

$20200 \cdot 0 \frac{1}{4}$

?

i.

E0-300:

$\infty$

1

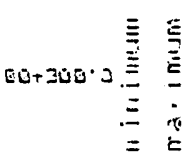

है

ฏ

포

을 

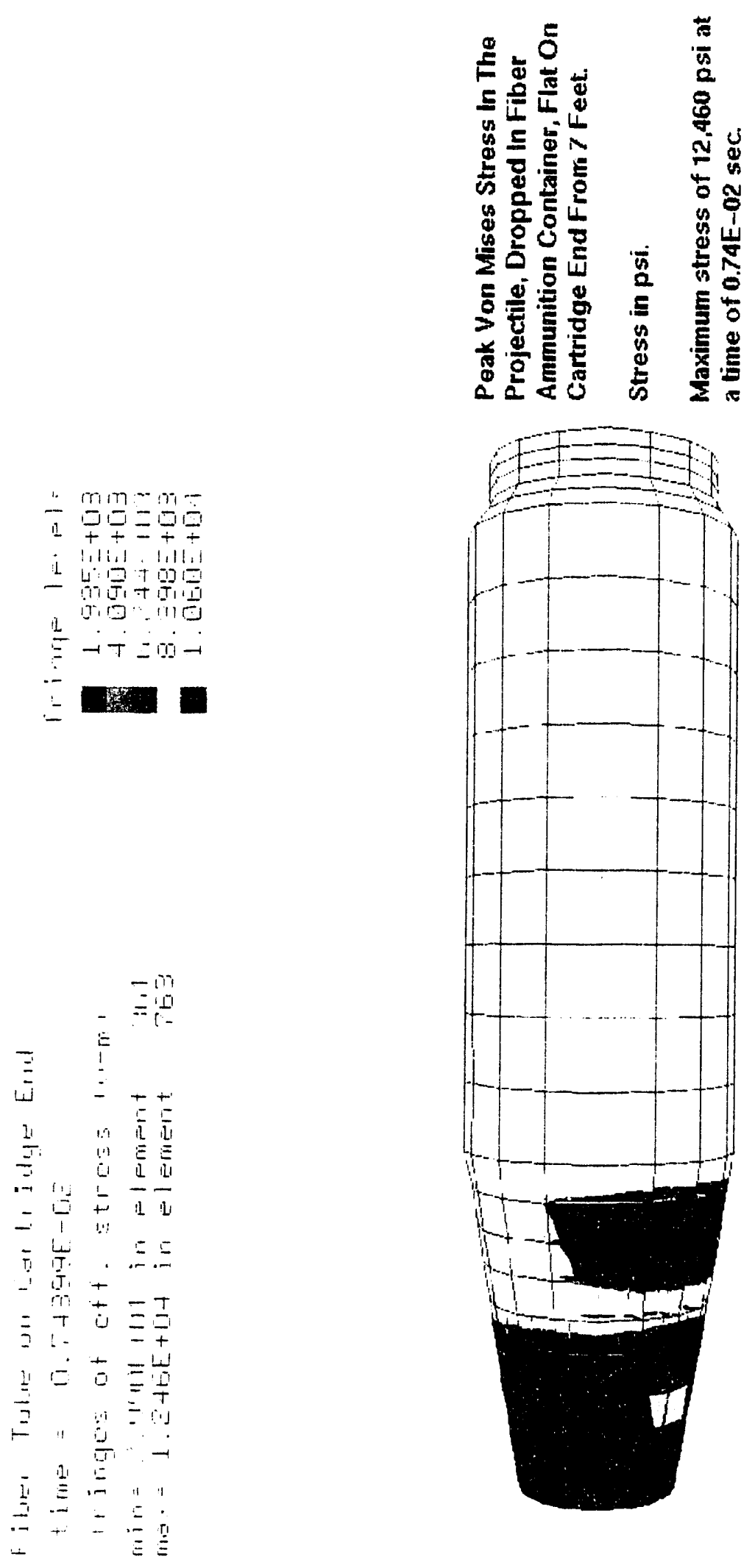

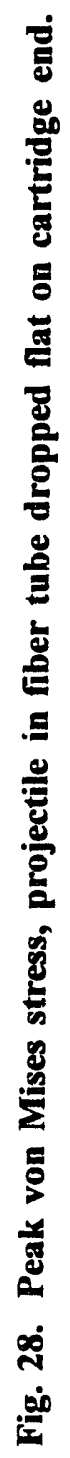



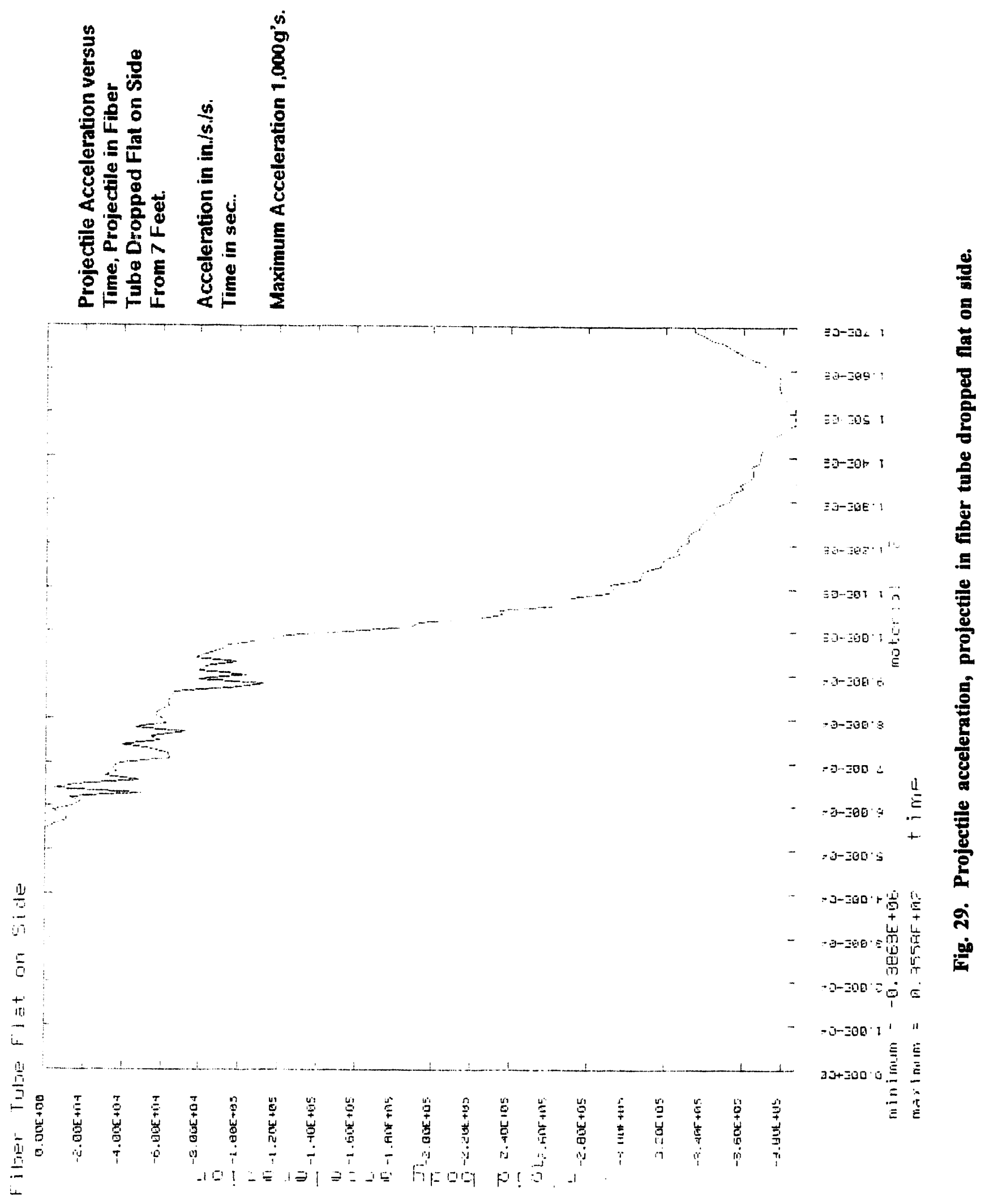
-

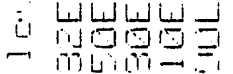

1) $1-54=7$

I

W

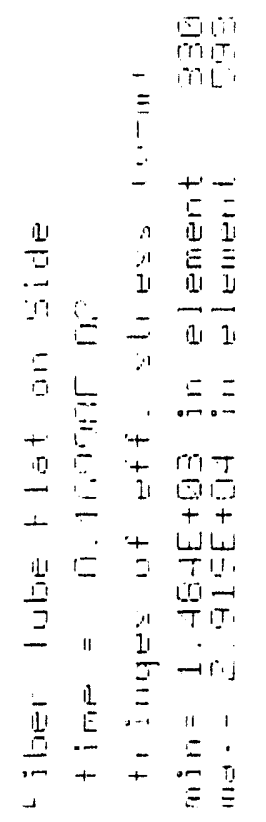

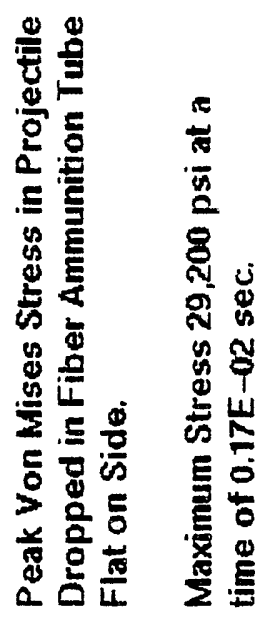

:

E

E

ت
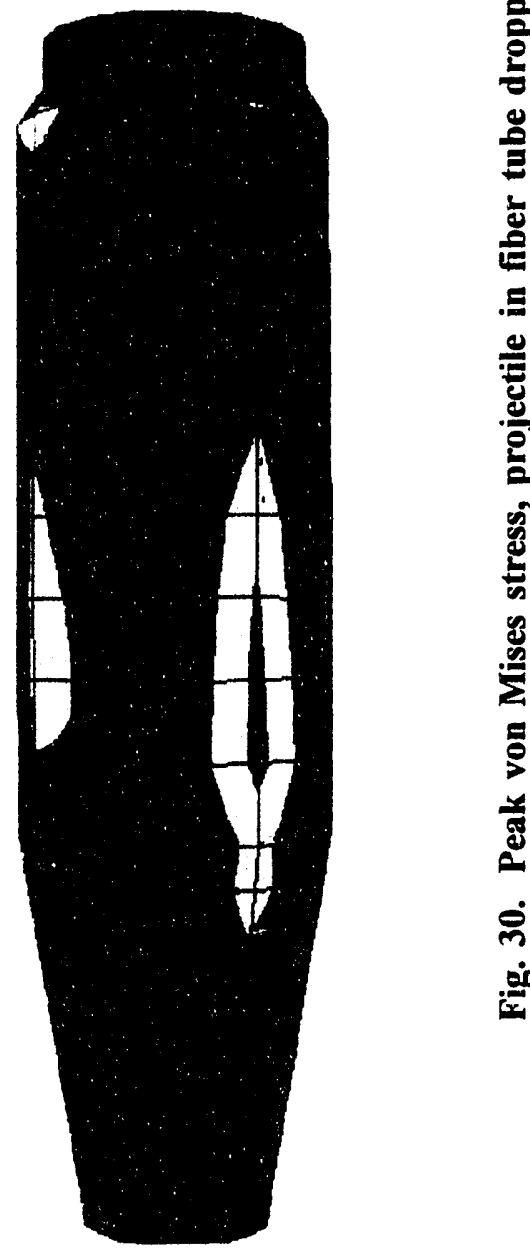

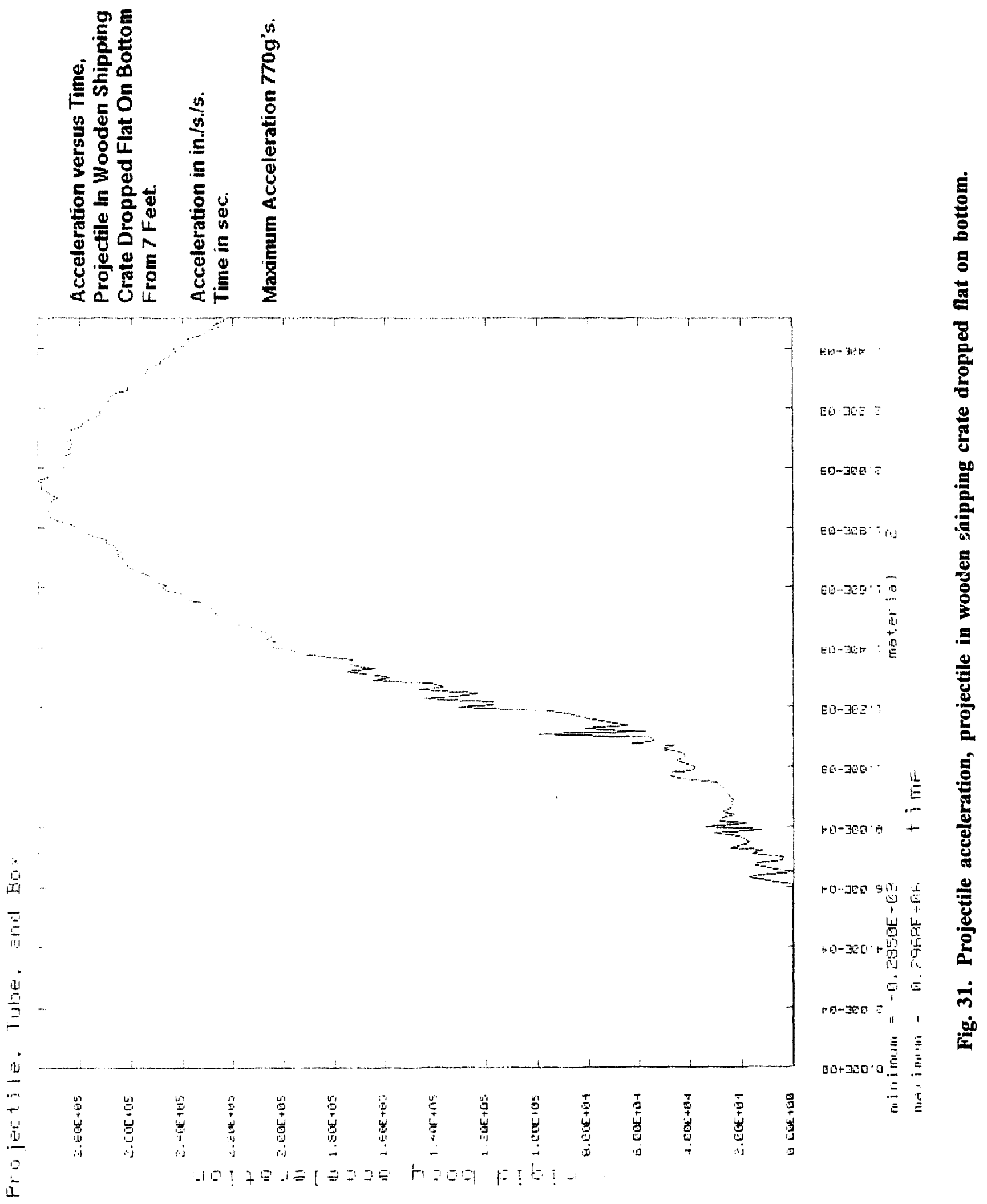

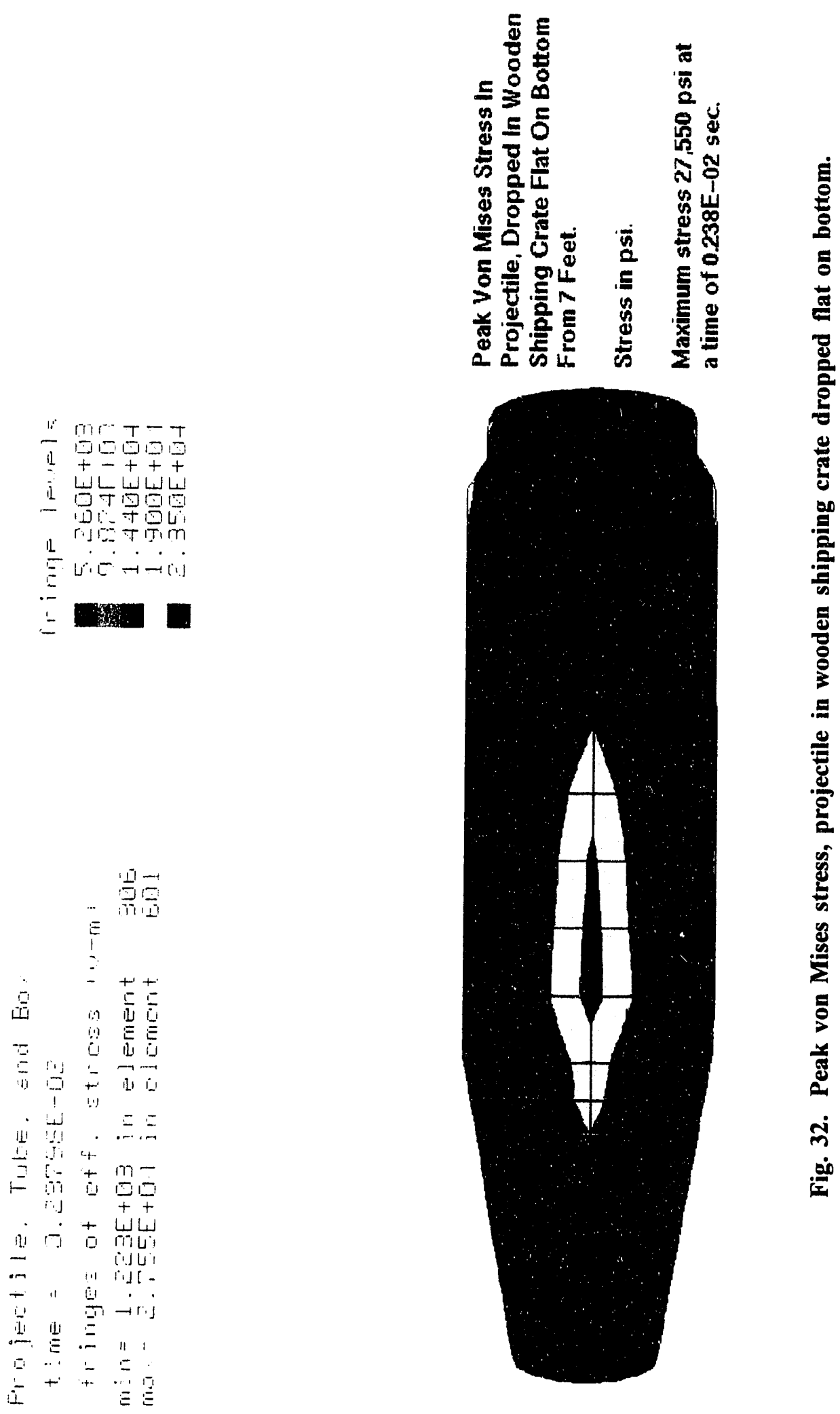


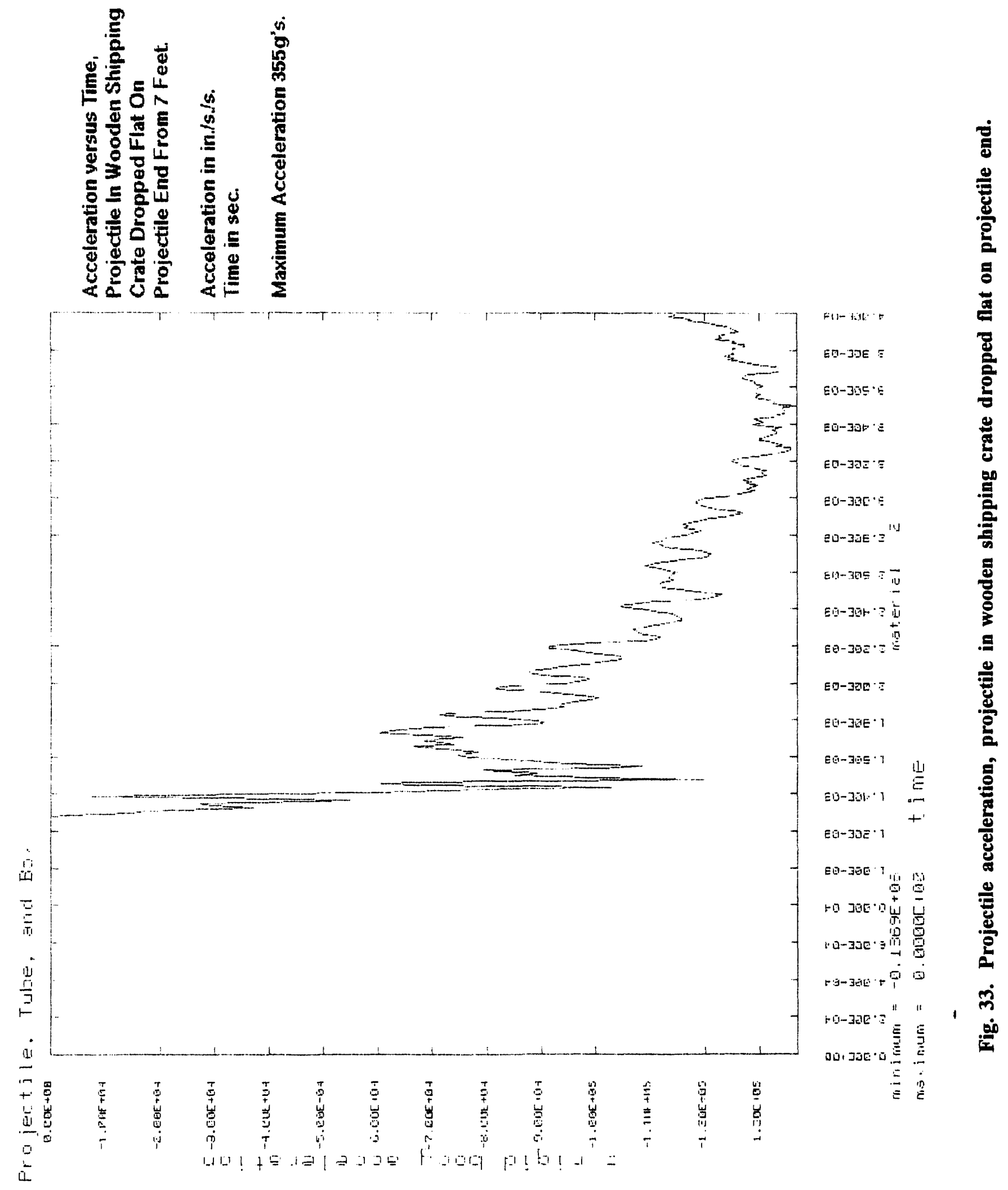



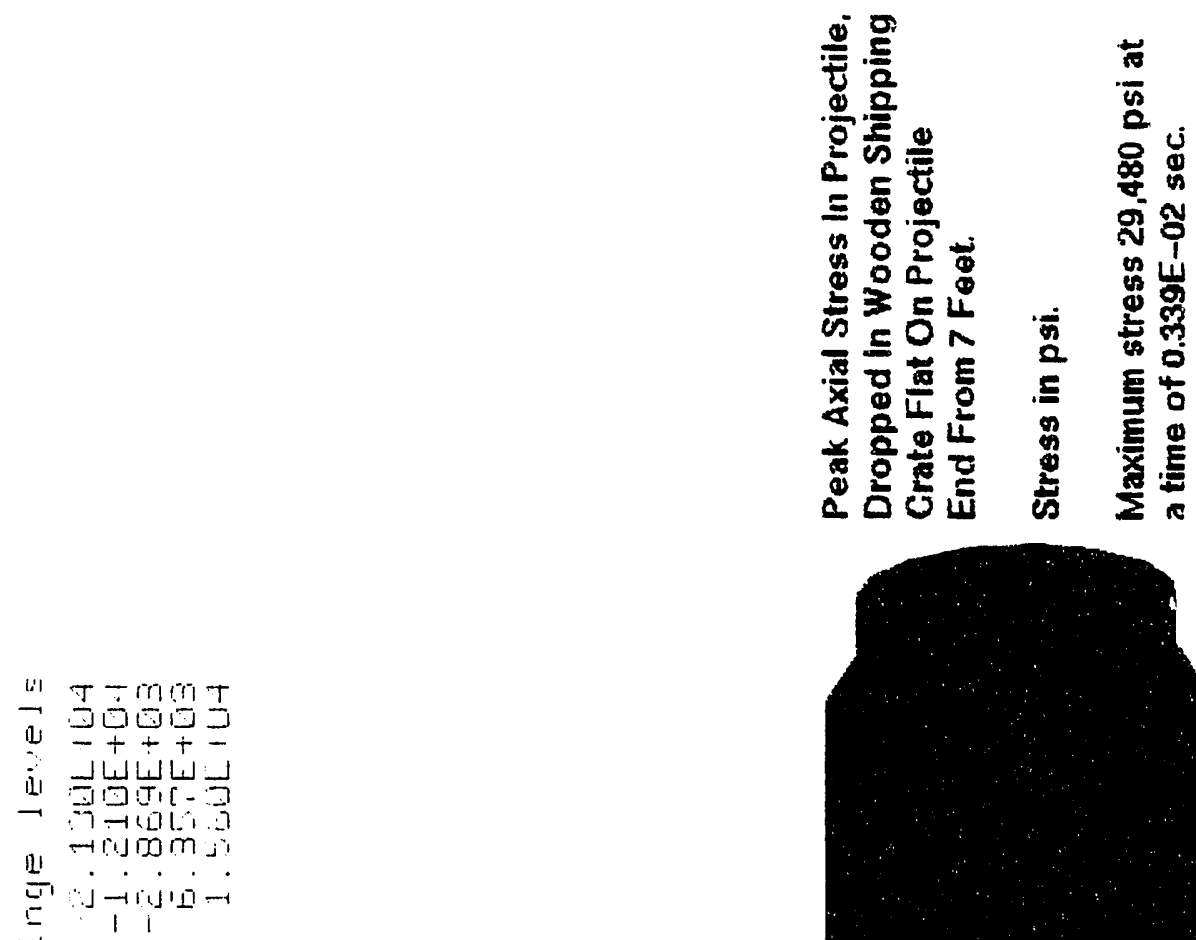

롱

IJT
GT T

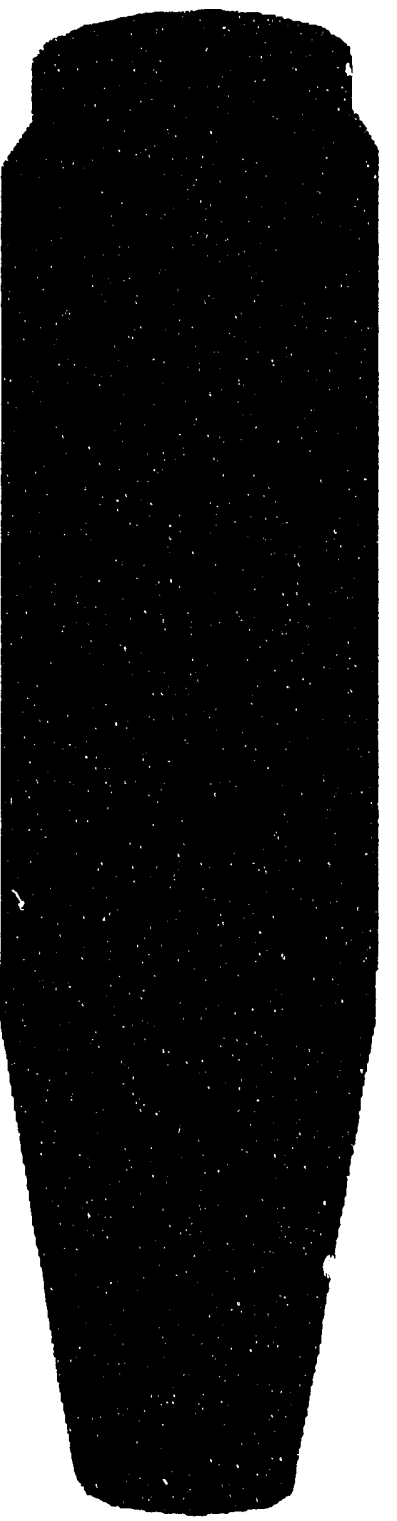

吾

흘

푼

䏠

.5

를

这

$\therefore$

三

i \begin{tabular}{l}
$\omega$ \\
\hline
\end{tabular}

$\underline{y}$

$=m_{01} 1 \frac{T}{t}$

i口岇它

‥

I. 口

- E m

- $+\overline{4}+\square$ 


\section{INTERNAL DISTRIBUTION}

1-3. R. M. Davis

4-6. J. H. Hannah

7. K. D. Handy

8. T. L. Ryan

9-12. J. C. Walls

13. D. S. Webb
14. ORNL Patent Office

15. Central Research Library

16. Document Reference Section

17. Laboratory Records Department

18. Laboratory Records (RC)

\section{EXTERNAL DISTRIBUTION}

19. Assistant Manager, Energy Research and Development, U.S. Department of Energy, Oak Ridge Operations, P.O. Box 2001, Oak Ridge, TN 37831

20. A. D'Angelo, Packaging Division, SMCAR-AEP, Picatinny Arsenal, NJ 07806-5000

21. N. F. Gravenstede, PM-AMMOLOG, Picatinny Arsenal, NJ 07806-5000

22. W. Healy, Packaging Division, SMCAR-AEP, Picatinny Arsenal, NJ 07806-5000

23. G. L. Kent, PM-AMMOLOG, Picatinny Arsenal, NJ 07806-5000

24. Robert J. Kuper, Chief, Packaging Division, SMCAR-AEP, Picatinny Arsenal, NJ 07806-5000

25-26. U.S. Department of Energy, Office of Scientific and Technical Information, P.O. Box 62, Oak Ridge, TN 37831 

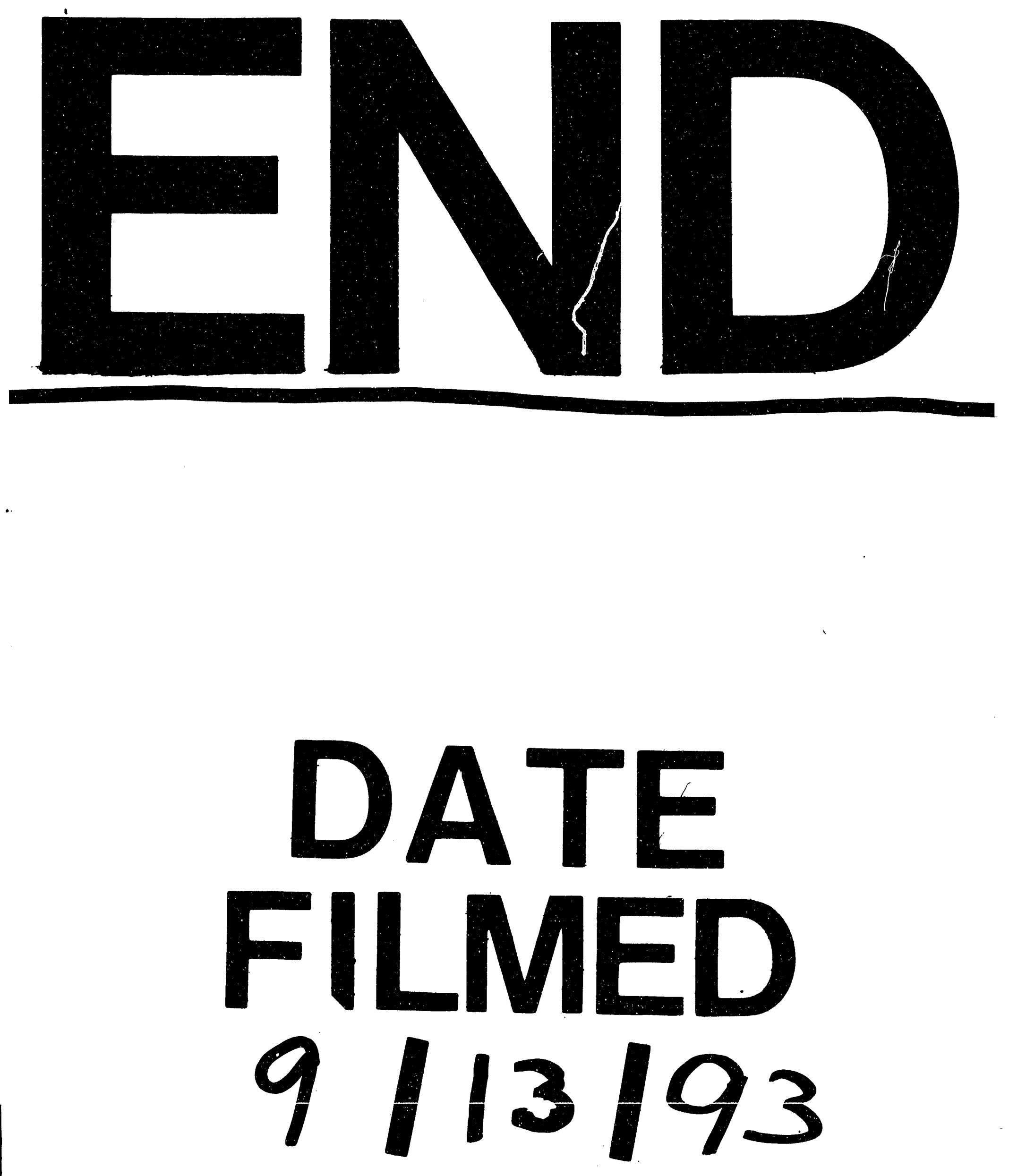


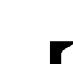



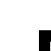

